\title{
DOSSIÊ
}

\section{OS INTELECTUAIS E A ESPECIALIZAÇÃO DA CULTURA}

Edson Farias*

Já consolidado no contexto sociológico desde a intervenção de Karl Mannheim (1974, p.40-68) sobre a "sociologia do espírito" 1 , a recorrente atenção conferida à camada social denominada por ele de "intelligentsia” (MANNHEIM, 1974, p.69-141) ou mais amplamente entendida como os "intelectuais" é parte constitutiva da história das disciplinas socioantropológicas e do pensamento social. Por mais variadas e polissêmicas que sejam as concepções sobre sua origem e natureza (COSER, 1970; LECLERC, 2004; ALTAMIRANO, 2006; PASSIANI, 2017, p. 16-47), os/as autores/as que refletiram sobre o tema concordam que se trata de um grupo de indivíduos - cada vez menos identificável como um só grupo - que se destaca do conjunto da sociedade e produz reflexões e significações acerca das experiências sócio-humanas (GRAMSCI, 1968; WINOCK, 1997; BOURDIEU, 1968; SAID, 2005). No anverso dessa conduta, a

\footnotetext{
* Pesquisador do CNPq. Professor do Departamento de Sociologia da Universidade de Brasília - UNB (Brasilia/DF/BR). E-mail: nilosed@gmail.com

1. A pesquisa e reflexão realizadas por Mannheim retomam o debate sobre a ontologia materialista do ser social em Marx, em particular o advento da divisão do trabalho, entre exercício espiritual (intelectual) e os fazeres manuais. Estribado à sua maneira na centralidade conferida à mediação do trabalho, quando escreve as Teses sobre Feuerbach, Marx (s.d) rejeita a apreensão da realidade apenas como o sensível e não como atividade, trabalho humano, isto é, exteriorização subjetiva nos termos antes já formulados nos Manuscritos Econômico-Filosóficos, de 1844. Por isso, à contramão de Feuerbach (1997, p. 56), Marx considera incompleta a crítica à religião, entendida enquanto o núcleo de toda alienação; o erro da proposição estaria em não compreender a natureza da prática constituinte da humanidade. Ou seja, o trabalho enquanto a produção material das condições de sobrevivência; mediante àquele se daria a objetivação humana, e o autor compreende nele a dinâmica de engendrar a atividade vital pela vontade e pela consciência, capacitando o indivíduo dessa espécie apreender a própria vida como objeto e, no exercício prático-reflexivo, extrapolar o imediato em favor da generalidade - quer dizer, em favor do conjunto das atividades sociais que determinam historicamente a condição da sua existência e do seu pensamento (MARX, 2004, p. 85).
} 
atuação desses/dessas agentes contempla mediações e traduções, colocando em mútua referência ideias, concepções, valores e normas, a princípio, incongruentes entre si. Levando-se em conta a importância socioeconômica hoje atribuída ao conhecimento e o peso crescente das políticas de significado, aumenta também a importância e abrangência do trabalho intelectual. Assim, a proposta deste dossiê volta-se para pesquisas, estudos e reflexões que abordam os diferentes significados e funções que estão sendo ou podem ser discursivamente relacionados à categoria dos/as "intelectuais" no mundo contemporâneo.

Em linhas bem gerais, o ponto de vista figurativo-processual respalda a chave teórico-analítica cruzando psicogênese (pesquisa acerca dos gabaritos de autocontrole na formação de padrões de economia emocionais) e sociogênese (o olhar lançado sobre as dinâmicas sócio-históricas de montagem de estruturas sociais) no entendimento dos intelectuais como quadro e posição social, neste dossiê. Em um primeiro momento, se reconhece os intelectuais internos à arquitetura cosmológica da civilização ocidental, em particular como nela a balança “eu-nós" pendera para uma noção individualizada de pessoa, a qual se impõe em detrimento de concepções mais coletivas, no âmbito de estruturas de relações sociais sempre mais urbanas e marcadas por coordenadas normativas impessoais relativas ao ordenamento político-jurídico e administrativo do Estado nacional centralizado (ELIAS, 1994). Nesse sentido, a fundamentação do eu epistêmico e judificativo fez-se intrínseca àquela concepção de eu cujas bases remetem à secularização da alma e da formação de uma psique intrasubjetiva $^{2}$ (MAUSS, 2003, p. 369-397), concepção esta que vazou os muros religiosos, propagando-se entre círculos eruditos renascentistas e pós-renascentistas com o aparecimento das academias, depois levados para o cerne dos sistemas universitários reformulados no século XIX, com a inauguração da Universidade de Berlim. Neste diapasão, a posição institucional do autor individual alinhou uma diversidade de formatos textuais abarcada pela denominação literatura (CHARTIER, 1994). Algo assim se deu, de um lado, pela incorporação jun-

2. Sem aderir à concepção de Durkheim (1989), para a qual o pensamento conceitual diz respeito ao estágio mais avançado do processo hominização, aqui, não se toma a formação dessa economia emocional tão somente condicionada pela centralidade obtida pelo raciocínio por intercessão, nos círculos teológicos da cristandade, à roboque das fórmulas racionalistas articuladas em torno da sistematicidade ética das condutas próprias aos credos monoteístas (WEBER, 1992; SCHLUCHTER e ROTH, 1999). Ainda que se ratifique a deflagração do processo de autonomia relativa do pensamento às restrições impostas às modalidades mágicas de pensar por adição/união, torna-se difícil atribuir um fator monocausal ao privilégio concedido ao modo de pensar conceitual-discursivo, entre as extrações de classes sociais nas quais se recrutavam os quadros intelectuais. No esquema da educação formal da Idade Média, as chamadas sete artes liberais contemplavam disciplinas divididas nos dois seguintes ramos: herdado do modelo greco-latino, o "trivium" - correspondia às artes "retórica", "lógica ou dialética" e "gramática"; o "quadrivium", para além de saberes igualmente provindos das matrizes da civilização ocidental, a "música" e a "aritmética”, abrangia a "geometria" e "astronomia", portanto, sinalizava determina circulação do conhecimento que, da Índia, avançou pelo Oriente Médio e aos centros de estudos muçulmanos (FRANCO JÚNIOR, 2001). Por outro lado, as frações ilustradas seculares fazem uso, exatamente, do pensamento abstrato no desmonte da hegemonia teológica-cristã no pensamento europeu, o que indica outros aprendizados (ROSSI, 1992). 
to aos sábios teológicos muçulmanos da exegese do livro sagrado; por outro, com o movimento pelo qual o registro fonético, pela força cosmopolita do latim como idioma das camadas eclesiásticas cultas à luz das suas congêneres seculares romanas, facultou ao registro escrito alfabético premência entre às demais formas expressivas (LE GOFF, 1989; ROMANO, 1989; VERGER, 1990). É importante ressaltar que este prestígio discursivo, mais tarde, viu-se transferido aos segmentos eruditos falantes dos códigos de expressão e comunicação verbal neolatinos e anglo-saxônicos, com a formação dos distintos mercados linguísticos articulados à ascendência dos Estados nacionais europeus e dos impérios coloniais lhes correlatos (BOURDIEU, 1996; GÓMEZ, 2003, p. 94-124). Sobretudo, com o advento da imprensa e no seu rasto dos mercados editoriais (BRIGGS e BURKE, 2016), a posição/função do autor/intelectual na trama da divisão do trabalho será fixada como uma lugar de subjetivação, caracterizado pelo exercício do controle da multiplicidade dos enunciados em circulação no cotidiano, em razão da antecedência gozada pela figura do sujeito de razão (cognitiva, estética e judificativa), com sua postura escolástica, apto ao trabalho da criação discursiva da conceituação (BOURDIEU, 2001; FOUCAULT, 2001).

Frente a essa tipificação preliminar atendendo à finalidade apenas de orientar o entendimento inicial da posição do intelectual, no conjunto dos artigos aqui reunidos interessa, de um lado, perspectivas orientadas para as atividades vinculadas à legislação do gosto e aos exercícios exegéticos e interpretativos que, extrapolando áreas específıcas do conhecimento, reverberam na promoção de repertórios conceituais e esquemas cognitivos com impacto nas trocas públicas de sentido. Por outro lado, são igualmente acolhidos olhares voltados aos posicionamentos de agências humanas e institucionais em processos de mediação em que contracenam diferentes âmbitos sociossimbólicos (culturas, civilizações, cosmologias, esferas sociais das experiências, entre outras). Nesta segunda vertente, atenta-se aos efeitos manifestos, por exemplo, na redefinição de objetos e fazeres artísticos, na demarcação ou borramento/apagamento de fronteiras geoculturais articuladas às divisões geopolíticas, no deslocamento de formatos expressivos e de suportes técnicos e institucionais de comunicação, na emergência da silhueta de novos sujeitos coletivos, na identificação de pautas de novas problematizações, e agendas temáticas com impactos no plano civil e estatal, entre outras possibilidades.

Ao longo deste ensaio introdutório, focaremos a posição dos/as intelectuais no quadro de interesses de uma sociologia da cultura contemporânea, a partir da proposição de que, cada vez mais, são estabelecidos novos parâmetros aos diversos regimes de práticas tanto nos domínios das expressões e das comunicações (logo das formações subjetivas e das interações) quanto nas decisões sobre os usos e, igualmente, na organização sociopolítica dos recursos simbólicos. Assim, enquanto uma ampla esfera social em que se ajustam mercantilização, modos de simbolização, além de técnicas e equipamentos, ainda nichos institucionais variados, a cultura contemporânea parece sagrar-se ao concatenar a dinâmica de lucratividade do capital com circuitos de produção e consumo de bens culturais e daí, interagir com as lutas em favor da afirmação de identidades e atendimento de estimas. Abrange, igualmente, as prestações de serviços relativas à mobilização de saberes 
e linguagens na evocação de memórias e patrimônios, mas na contrapartida de equilíbrios de poderes, sincronizando ordenamentos locais, nacionais e transnacionais.

Nesse sentido, em um primeiro momento, retemos a ideia de "cultura-mundo", proposta de Lipovetsky e Serroy (2011, p.31-61). Para um e outro autor, a cultura contemporânea se alia ao hipercapitalismo e, também, ao hiperindividualismo e à hipertecnologia. Ou seja, a cultura contemporânea é indissociável da universalização da lógica mercantil com seus imperativos de eficiência e concorrência. Mas, trata-se da configuração desta lógica tanto no apelo quanto na concretização dos usos de bens e serviços respaldados em uma complexa divisão do trabalho concatenando sedução, profıssionalismo e dinheiro, estabelecendo sintonia intrínseca entre lucro e desejo. Logo, a mesma cultura contemporânea contracena, igualmente, com a robustez adquirida pela subjetividade em detrimento dos aportes coletivos (parentesco, religião, enquadramentos político-ideológicos, nação, entre outros), realçando, em especial, a inviolabilidade da liberdade como direito inalienável do indivíduo humano, e o estado de felicidade seria a realização desse ideário. Com isto, tonificando os temas da identidade e das estimas, para além do bem-estar material e da segurança. Ainda, esta cultura, em sua amplitude mundial, é simbiótica de uma ecologia sociotécnica relacionada à centralidade obtida pela tela audiovisual e da linguagem digital seja na produção, seja na transmissão e, também, no acesso e usos das formas tomadas pela simbolização das experiências, na sua transformação em saberes com efeitos indeléveis sobre os aprendizados, na modelação das vontades e, assim, fazendo-se elucidativa dos tipos de desempenhos de práticas que definem regimes institucionais no mundo, hoje.

Acerca desse último aspecto, referido à abrangência desta "cultura-mundo", os mesmos autores inserem uma posição analítica e interpretativa posta na contramão de ideias como a do "choque de civilizações” e do declínio dos Estados nacionais. Para eles, é insustentável a tese de uma homogeneização global, isto na medida em que, se as civilizações existentes reafirmam as suas respectivas proposições de autoimagem, chegando mesmo a abraçar alternativas fundamentalistas, ao mesmo tempo interagem e se interpenetram, deslocando e recriando tradições, reescalonando suas respectivas heterogeneidades. Portanto, tomada de empréstimo de Edgar Morin ${ }^{3}$, eles recuperam a concepção de a modernidade constituir a primeira civilização de fato universal, para sublinhar que isto não significa que ela: Aboliu a diversidade das culturas particula-
ristas no mundo. (Pois) Sobre um pano de
fundo globalista de agora em diante con-
vergente e de origem ocidental, podem er-
guer-se instituições políticas, ideológicas e
valores dominantes que não são de modo al-

3. Nos anos de 1960, Edgar Morin (1990) sublinhava a novidade da Cultura Popular de Massas na medida em que sua narrativa e seus símbolos evocariam uma nova mitologia; nesta última, o prosaico e o cotidiano estariam elevados ao status de uma epopeia fazendo convergir técnica e moralidades. Constituindo, assim, um novo panteon de ídolos e heróis saídos do cinema e do esporte. Esta mitologia estaria na base de um novo "antrophos”, de um "novo homem” agente da primeira, de fato, civilização universal. 
gum os partilhados pelo Ocidente liberal: a globalização hipermoderna não traz consigo de maneira alguma o triunfo certo das democracias liberais. (LIPOVETSKY e SERROY, 2011, p.65)

A partir da proposição sobre o difusionismo dos valores e instituições do Ocidente, em especial, da democracia liberal, os autores assinalam as vicissitudes que estariam gerando formações societárias e culturais em nada afinadas com a matriz europeia e estadunidense. Fator decisivo a esse respeito estaria, para um e outro intérprete, na persistência do Estado-nação como elemento de administração, regulação e coordenação da vida planetária, o que se faria sentir no fato de que as forças transnacionais "promovem a valorização da diferença e da identidade nacional, o apego ao território e à memória, mas também egoísmos econômicos" (LIPOVETSKY e SERROY, 2011, p.65).

No instante mesmo em que o argumento proposto é sugestivo, ele igualmente suscita dúvidas e, os dois autores fornecem ingredientes para isto quando, mais adiante, tratam da cultura-mundo como aquela em que o mundo das marcas e do consumo, o mundo mercantil, tornar-se-ia sinônimo de cosmo cultural. A cultura-mundo se define, então:

(...) em primeiro lugar pelo fim da separação entre cultura e economia, em segundo lugar pelo significativo desenvolvimento da esfera cultural, em terceiro lugar pela absorção dela pela ordem mercantil. A cultura que caracteriza a época hipermoderna não é mais o conjunto das normas herdadas do passado e da tradição (a cultura no sentido antropológico, nem mesmo o "pequeno mundo" das artes e das letras (a alta cultura); ela se tornou um setor econômico em plena expansão, a tal ponto considerável que se chega a falar, não sem razão, de "capitalismo cultural". A cultura-mundo designa o sistema econômico-cultural do hipercapitalismo globalizado. (LIPOVETSKY e SERROY, 2011, p.68)

Ora, ao sublinharem um remanejamento profundo em que se torna hegemônico um capitalismo global cuja lógica sistêmica está definida pelo vínculo entre cultura e economia, nesta atual equação geopolítica planetária o que parece nitidamente sobrar é a esfera política representada pelo Estadonação. Deste modo, a "cultura-mundo" é tradução de um arranjo societário em que o problema da integração se recoloca, porém, não mais no nível de integração segmentar, tampouco daquele do modelo da centralização estatal. Nesse sentido, parece-nos, sim, válido reiterar a posição dos autores acerca de que a cultura contemporânea não condiz com o cenário belicoso em que civilizações se colocam em confronto e nem com aquele de um achatamento mutilador e dissolvente das diferenças étnico-históricas. Contudo, ao corresponder a um mundo em que se dá a crescente competição entre culturas que, por sua vez, corresponde à estilização de diferenças sociossimbólicas enquanto diversidades étnicas, sexuais, de gênero, etário-geracionais, entre outras, as quais, nos tantos formatos adquiridos por estas qualidades, compõem os catálogos de um mercado da alteridade, deixa em xeque a contrapartida do monopólio de sentido legítimo exercido pelo Estado-nação; monopólio ainda exercido, em parte, nas maneiras como as narrativas da identidade e da cultura nacional são figuradas nos bens simbólicos e em seus suportes materiais.

Deste modo, volto ao modelo de inferência sociológica das conexões complexas com o propósito de tratar do problema acer- 
ca dos níveis de integração em relação ao nexo intelectuais e estruturas sociais. Mas é preciso frisar que o faremos no sentido de apreender e discutir a correlação entre a especialização da cultura, no instante de sua universalização pelo viés de cultura mercantil nos limites do ambiente da globalidade, e as características que seriam próprias ao tipo de governança prevalecente no que aqui passaremos a chamar de contexto pós-nacional. A opção analítica que adotamos para nos aproximarmos do problema acerca da especialização da cultura toma por referência a perspectiva adotada por Zygmunt Bauman, e isto nos conduz à sua abordagem sobre a triangulação entre intelectuais, cultura e modernidade.

\section{$* * *$}

Embora só lançado no Brasil em 2010, a publicação original de Legisladores e Intérpretes: sobre modernidade, pós-modernidade e intelectuais (Legislators and Interpreters: on modernity, post-modernity and intellectuals) se deu em 1987, na Inglaterra, e tinha o propósito claro de participar de um acalorado debate travado na época: o enfrentamento entre defensores de um projeto inacabado da modernidade (HABERMAS [1992], sobretudo) e os que anunciavam que, sobre a ruína da condição moderna, erguia-se outra, a pós-modernidade - talvez, no momento, Jean-François Lyotard concentrasse essa última postura ${ }^{4}$. Ao levar a sério os comentários tecidos pelo autor no prefácio da edição brasileira, Bauman encontra uma alternativa de se inserir no debate, justamente, tomando por objeto os maiores interessados na disputa: os intelectuais. Investido dessa posição, não lhe cabe tomar partido acerca de um ou outro polo, tampouco crer no desmonte do tipo moderno de produção intelectual, até porque observa a interação entre a crítica pós-moderna e a permanência da modernidade como alvo a ser referido continuadamente ${ }^{5}$. 0cupa-se da disputa, etnografando os localizados em cada uma das posições, ou seja, os "modernos" e os "pós-modernos". Interessa-lhe os itinerários para obter uma visão abrangente da topografia do espaço social ocupado/constituído por ambas as linhas de forças opositivas e complementares.

A questão que motiva o sociólogo polonês é a alteração no perfil destes personagens - os intelectuais - da trama e da história sociocultural do Ocidente e seu argumento: a passagem dos intelectuais da posição de "legisladores" do projeto de modernidade para a de "intérpretes" da pósmodernidade. Se ele tem em mente os efei-

4. Embora sucinto, um documento importante deste debate é a interlocução entre Habermas, Peter Bürger e Lyotard - ver Revista Arte e Cultura, n. 10, 1991.

5. A perspectiva da pós-modernidade da qual olha o sociólogo, inspirado pela tradição crítica, diz ele, "significa sobretudo o rasgamento da máscara das ilusões; o reconhecimento de certas pretensões como falsas e de certos objetivos como inatingíveis, e nem, por isso mesmo, desejáveis. A esperança, que guia esse estudo, é de que, sob essas condições, as fontes de poder moral que, na moderna filosofia ética e prática política, estavam escondidas da vista, possam se tornar visíveis, e as razões para sua passada invisibilidade possam ser mais bem entendidas: e que, como resultado, as oportunidades de 'moralização' da vida social possam - quem sabe - ser reforçadas. Resta a ver se o tempo da pós-modernidade passará para a história como o crepúsculo ou como renascimento da moralidade” (BAUMAN, 1997, p.08). 
tos deste deslocamento, mas igualmente lhe interessa as implicações que o teria gerado.

Em relação ao primeiro ponto, o autor nota uma alteração qualitativa no tocante à composição deste segmento social: uma complexa divisão do trabalho se estabelece, desmembrando-o entre intelectuais "gerais" e "parciais”. A contradição entre ambos estaria no acirramento da especialização funcional que garante a existência dos últimos em detrimento do conforto que assegurava o domínio aos primeiros de todo o território do conhecimento, da produção de sentidos e da validação de crenças. Certo politeísmo acompanhado de uma competição crescente entre alternativas de significação parece constituir os efeitos dessa clivagem; consequências cujos desdobramentos se fazem sentir na erosão que dilui a pretensão universalista. Na contrapartida, no compasso da silhueta do "intelectual regional" em Foucault e Deleuze (1979, p. 69-78), admite, mesmo valoriza, a contestação de qualquer primado unicista, totalizante, aderindo às concepções de parcialidade, regionalidade, imprecisão, deslocamento, entre outros. Portanto, aos modernos importava a tarefa legislativa calcada na condição extraordinária e desterritorial, facultando-lhes o direito de se autocelebrarem tanto o crivo quanto o oráculo, supremos de uma sociedade laicizada, posicionar e fazer juízos imparciais frente a qualquer tradição localizada e sujeita às injunções dos interesses cotidianos $^{6}$. Para os pós-modernos, ao se autorreconhecerem igualmente territorializados e inseridos nos parâmetros de um determinado círculo hermenêutico, a tradução entre os dois universos culturais seria o mais apropriado. A tradução diz respeito ao exercício interpretativo que se funda no esforço compreensivo, mas igualmente tem ciência de consistir em uma imputação circunstanciada por condicionantes de diversas ordens. À maneira do antropólogo geertzniano (GEERTZ, 2002), essa inserção delicada opta pela "descrição densa" do convívio nativo, sabendo se tratar de uma

6. Sem dúvida, Jean Paul Sartre ilustra como ninguém esse personagem. Ao lado de Simone de Beauvoir e Maurice Merleau-Ponty na edição da revista Temps Modernes, desde o final da década de quarenta, Sartre definiu um eixo de interseção entre literatura e política no qual a linguagem corresponderia a um instrumento conciliando a "positividade de um discurso político e ideológico proferido com clareza e a negatividade própria da literatura, quer dizer, a sua capacidade de trabalhar o implícito e o não-dito dos discursos, a fazer a aparecer a contradição que jaz no coração das representações instituídas, pronta a subverter a positividade da palavra socializada” (DENIS, 2002, p.278). Este projeto fundado doutrinariamente sobre a concepção existencialista de que a existência humana precede a toda essência veio na esteira da luta contra a ocupação nazista e estava comprometido, apesar dos reveses e do afastamento do autor do PC francês, com o comunismo soviético, na situação da Guerra Fria. No embalo da vitória colhida na situação da resistência frente ao inimigo fascista e em sintonia com a teleologia revolucionária marxista filtrada pela interpretação desenvolvida no livro O Ser e O Nada (SARTRE, 1997), considerando para isso o legado fenomenológico de Husserl e Heidegger, entre as facções à esquerda da sociedade, a Sartre foi delegada a autoridade para reivindicar um tratamento ao tema da consciência e da ação cujo foco era a tensão entre liberdade e determinação no modo como a sociedade moldava os indivíduos. Estes seriam, no terreno das possibilidades, capazes de ultrapassar os limites nas suas escolhas e estariam, a um só tempo, comprometidos com toda a humanidade. 
situação interativa entre duas tramas de signifıcados e a comunicação estabelecida está, assim, gerando novas significações o que, mais tarde, Homi Bhabha denominará de "terceiras culturas" (BHABHA, 2001; RUTHERDORD, 1996) ${ }^{7}$.

Já em relação às implicações inerentes a essa disputa territorial interna ao campo intelectual, Bauman irá atentar à complexificação e à especialização mesma da cultura. Levanta a hipótese de que:

(...) o surgimento e a influência das duas variedades distintas de práticas intelectuais podem ser mais bem-entendidas quando consideradas em comparação com as mudanças nas relações entre o Ocidente industrializado e o resto do mundo; na organização interna das sociedades ocidentais, na situação do conhecimento e dos produtores de conhecimento dentro dessa organização de vida dos próprios intelectuais. (BAUMAN, 2010, p.21-22)

\section{É deste modo em que se propõe:}

(...) explorar as condições históricas sob as quais a visão de mundo e a estratégia intelectual modernas se formaram e as condições sob as quais foram questionadas e em parte suplantadas, ou pelo menos complementadas, por uma visão de mundo e uma estratégia alternativas, pós-modernas. (BAUMAN, 2010, p.21).
Numa tentativa de aplicação da "hermenêutica sociológica” à metanarrativa dos intelectuais no Ocidente, a proposta de Bauman está em evidenciá-los, tirando-os da opacidade em que costumam se encontrar no que concerne às mudanças culturais e aos processos sociais de um ponto de vista mais amplo. Para isto, ele recorre ao modelo de análise etiológica proposto pelo antropólogo Paul Radin (2002), em que o exercício de autorrevelação transcultural faculta desvelar o modo de constituição do próprio intelectual em sua sociedade de origem, e esta se torna a condição para verificar a presença e a natureza desta presença dos "filósofos primitivos". Bauman observa, a partir das elaborações do antropólogo, como se delineiam certas características comuns entre os intelectuais, em especial seu isolamento no conjunto societário, o que lhe garante uma distância tanto para julgar os outros regimes de práticas quanto para oferecer formulações que a princípio não estariam contaminadas, seja pela parcialidade ou pela inconstância.

Com efeito, Bauman se volta para a figura do intelectual no Ocidente e se depara com a presença recente do termo e do seu significado, datada do final do século XIX, ao que parece na França, tendo por emblema a célebre carta J'accuse, escrita pelo romancista Emile Zola ao presidente da França, reivindicando a revisão do julgamento que condenou por traição o oficial judeu

7. Respaldado na desconstrução derridadiana da unicidade fônica do eu epistêmico (DERRIDA, 2017) e no esquema da polifonia, em Bakthin (1996), a corrente pós-modernista na antropologia estadunidense extremou o perspectivismo interpretativista. Com isto, ressaltaram o papel de tradutor, já que o pesquisador deveria atentar-se à multivocalidade e à multiplicidade de gestos dos/as seus/suas interlocutores (as). Como observa James Clifford (2002, p.179-227), o ponto nevrálgico reside nos riscos da tradução intercultural mais que mutilar - pois toda tradução é por natureza "traidora" -, forçar ao silêncio a alteridade sobre a qual fala, em respeito ao imperativo de que a descrição e análise se mantenham fiéis ao realismo etnográfico. 
André Dreyfus. No documento, valendo-se das prerrogativas de valores universais, o autor é tenaz na defesa do militar, denunciando o antissemitismo que teria orientado o desfecho da decisão judicial que o condenou (Rouanet, 2006, p.71-72). Importa-lhe, antes, a coincidência histórica entre a demarcação da classificação de um grupo de status, tendo por núcleo a excelência e soberania do filósofo no direito/dever de interferir no mundo público, e o declínio da concepção de razão substantiva, abarcando em seu seio os planos científicos, morais, estéticos e políticos (BÉNICHOU, 1981). Persevera o autor que a tenacidade na defesa do intelectual esteve em consonância com a narrativa mítica acerca dos philosophes iluministas (CHARLE, 1990; BADINTER, 2007). Enquanto uma estratégia, a evocação desse herói-civilizador permitiu não apenas respaldar o poder simbólico da autonomeação desta elite, mas igualmente garantir os dispositivos de recrutamento dos seus membros. A antecedência mítica dos philosophes estava fundada na utopia da ilustração do século XVIII (TOURAINE, 1994), ou seja, na emancipação humana pela intervenção da transparência racional, controlando tanto a fúria interna à animalidade existente no homem quanto as turbulências relacionadas à natureza externa. Contudo, destaca Bauman, o empreendimento mítico-utópico não pode ser isolado das condições históricas do poder político francês do mesmo século XVIII, no qual esses personagens puderam se colocar como anunciadores e juízes de um projeto da "boa sociedade”. Eles, aí, constituíam uma rede, a Republique das Lettres, composta pelas sociétés de pensée. Enquanto uma noblese, os philosophes se distinguiam como um padrão ideal de humanidade, uma reserva moral assentada no credo na razão habili- tada ao renascimento da sociedade. A coesão deste grupo pelo acato da imagem e do significado de serem um círculo cerrado em suas próprias fronteiras, dentro das quais se cultuava uma razão laica e não imiscuída nas mesquinharias e parcialidades, naquele instante, fazia frente a um conjunto de impasses e lacunas marcantes no contexto social da França: uma monarquia absoluta madura e desgastada, abrindo flancos para posturas conservadoras e revolucionárias que complementassem, dando acabamento ao processo de centralização estatal; contudo, a nobreza cortesã mostrar-se-á incapaz de exercer a liderança deste processo, tampouco oferecia subsídios para implantar um controle social efetivo; assim, o declínio da nobreza se deu antes que qualquer outro grupo emergisse com autoridade para assumir a tarefa de classe dominante (TOCQUEVILLE, 1997; ELIAS, 2001).

Desde já se torna claro o que interessa a Bauman: a correlação estabelecida no curso histórico das sociedades nacionais europeias, entre as facções ilustradas e outros segmentos dominantes na composição dos espaços de poder. Desta maneira, executa uma sociogênese do nexo poder/conhecimento. Ou melhor, volta-se à apreensão da dinâmica histórica em que o ponto de vista dos philosophes sai de uma posição marginal e emergencial até se impor como uma ortodoxia. E o que seria próprio a este ponto de vista? Exatamente a credulidade na competência humana, por intermédios dos seus recursos cognitivos, mentais, de domar os fatores que geravam insegurança. Ora, a ascendência deste ponto de vista, detecta o autor, ocorre no mesmo momento em que sobre as ruínas do "mundo estável" e "pacato" medieval, erguia-se a aurora da modernidade. 0 desmonte paulatino da ordem patrimonial e comunitária introduz a 
aceleração dos ritmos, os deslocamentos de coisas, pessoas e ideias. Impõe-se a desestabilização como um fator estrutural às vidas e socialidades. Uma atmosfera de medo se propaga, generalizando-se. A figura do "homem livre" - mais tarde explorada por Marx, em 0 Capital -, do vagabundo transeunte sem paradeiro devido ao corte dos laços e obrigações com a terra e o senhor, é paradigmática:

Falando do ponto de vista sociológico, os homens livres vagabundos expunham a obsolescência dos mecanismos tradicionais de reprodução social; por conseguinte, concentraram sobre si o ódio e a ansiedade nascidos de uma nova incerteza. 0 medo era autocorroborante, era também irreduzivel, à medida que os processos de cercamento dos campos jogavam cada vez mais pessoas nas estradas, e que os hábitos móveis dos homens livres multiplicavam seu número verdadeiro na consciência pública: cada homem livre visitava e assustava muitas localidades num curto período de tempo. (BAUMAN, 2010, p.65).

É na contrapartida desses deslocamentos socioestruturais na Europa, em que o desprendimento de vidas humanas da terra e das comunidades campônias, tornando-as mão-de-obra a serem comodificadas no interior de um mercado em crescente unifıcação, que o Estado centralizado se impõe como "agente do poder disciplinar", de acordo com o vocabulário focaultiano, quando foca o controle e a regulação de populações humanas mediante o mútuo engendramento de discursividades em que as populações são definidas objetos para a interpelação de sujeitos de saber com a operacionalidade contínua de exercícios de comando (FOUCAULT, 2008). E algo assim, acentua Bauman, dizia respeito, inicialmente, à domesticação desses magotes humanos, deixando-os em situação permanente de objetos de vigilância por parte de instituições dotadas de recursos de controles totalmente assimétricos em relação às populações submetidas aos seus desígnios. Uma das alternativas adotadas no movimento desta nova forma de controle social é a intervenção do educador que, à maneira do pastor de ovelhas ${ }^{8}$, é reconhecido por ser dotado do poder de condução e isto corresponde, por outro lado, à incapacidade de autodireção por parte dos "arrebanhados":

A institucionalização da vigilância assimétrica ofereceu uma estrutura arquetípica na qual esta compreensão da "insuficiência", "incompletude" ou "imaturidade intrínseca" dos seres humanos podia ser de novo forjada em ação prática, e, desse modo, testada e reforçada. Essa prática, contudo, que de um lado reproduzia e "objetivava" as imperfeições do indivíduo humano, estabelecia na outra ponta do espectro de poder o papel do educador - o especialista em fazer os seres humanos ascenderem à perfeição exigida pela ordem social, da forma adequada, renomeada agora de "bem comum". (BAUMAN, 2010, p.74-78).

A delimitação e a incompatibilidade estabelecida entre razão e paixão se tornam o

8. Há um diálogo entre o emprego dessa imagem por Bauman e as formulações foucautianas sobre o advento da arte de governar centrada na figura do pastor, em meio à afirmação da cristandade católica no Ocidente (FOUCAULT, 2008). 
reverso da medalha, para o autor, da maneira como se conjugaram a ascensão do educador e a consolidação da prioridade moral do bem-comum, face normativa da ordem social consubstanciada no Estado centralizado. Sob esses trilhos, perpetuar a atitude ordeira, civil, estava relacionado tanto à educação dos homens, suscitando sua competência de autocontrole, quanto ao reconhecimento por parte destes, da autoridade de controle coletivo exercido pelo ordenamento estatal. Bauman mostra de que forma, nos debates tratados entre pensadores na aurora moderna, a separação entre interesse e paixão também tinha por objetivo traçar a distinção do que correspondia ao julgo das vontades inteiradas no convívio social daquele plano natural, desprovido de uma regulação possível a partir do acordo das vontades, quer dizer, da falta de um artifício institucional gerando previsibilidade (FARIAS, 2009, p.17-58). Em todos esses aspectos, destaca-se a posição estratégica ocupada pela ideia de planejamento como signo de uma competência intelectual apta a fazer frente aos desmandos de qualquer natureza, sobretudo aqueles provenientes da permanência de costumes - tradições antigas, tomadas como inadequadas para o tempo presente (BURKE, 2010). Com isto, as práticas populares passam a ser alvo de desqualificação. Mais ainda. Tornando-se objeto de repressão, seus agentes são postos sob a vigilância, são coagidos à pedagogia racionalmente informada.

A denominação do intelectual como "jardineiro" se faz em obediência às prerrogativas deste contexto em que as elites ilustradas ascendem e se efetivam como detentoras de um saber que as autoriza formular artefatos cognitivos com fundamentos e fins morais calcados na utopia da "boa sociedade”. São, ao mesmo tempo, planejadores e legisladores que julgam outras práticas e propõem novas atitudes de acordo com o postulado do bem-comum e, assim, fazem dueto com as razões do Estado centralizado. Civilizar afirma-se, então, como um projeto visando formar almas e corpos para que estes não repercutam no coletivo à maneira das ervas daninhas no campo, rompendo os posicionamentos estabelecidos, enfim, promovendo a desordem ${ }^{10}$.

Contudo, Bauman observa que o desenlace desta parceria entre elites ilustradas e ordem estatal centralizada ocorreu nas vicissitudes geradas pela sua própria dinâmica sócio-histórica, ou seja, decorreu da implantação da modernidade como modo de vida e narrativa legítima, autodefinindo-se

9. 0 recurso a essa categoria aparece no livro Modernidade e Ambivalência, em que Bauman (1999, p.09113) identifica uma ciência da jardinagem no andamento de montagem da modernidade europeia. A seu ver, essa ciência corresponde ao combate incessante a toda sorte de ambivalências decorrentes do próprio avanço da sociedade-nação industrial burguesa. 0 concerto entre Estado e intelectuais teria desempenhado papel nevrálgico nessa guerra moral-cognitiva.

10. A questão civilizatória posta na ponta da lança das elites ilustradas europeias, a seu ver, respaldava-se num alicerce de uma moral unicistas. Ora, lembra o autor que os fenômenos humanos são em seu âmago ambíguos, logo, todo impulso moral é essencialmente ambíguo, já que não se ajusta ao cálculo dos meios e assim, por aflorar na contingência do estar face a face com o outro, a condução moral se faz impossivel de tomá-la como previsivel à luz de princípios éticos filosóficos, abstratos. Os atos morais, ao estarem fundados no ser para o outro - de acordo com o filósofo Emmanuel Lévinas (2005) -, não dizem 
e apresentando-se como o ponto culminante da razão e da civilização de toda a humanidade. 0 autor argumenta que o traço bélico de cruzada moral e epistêmica desta narrativa e da atitude lhe correlata sempre esteve, ao mesmo tempo, pressionada pelo objeto a que deveria combater: a desordem, o irracional, aquilo sobre o que deveria legislar a razão emancipada e substancial:

A modernidade foi vivida numa casa mal -assombrada. Ela foi uma idade de certezas, mas teve seus demônios; era a segurança de uma fortaleza sitiada, a confiança do comandante de um exército até então, graças a Deus, mais forte. Ao contrário da certeza dos escolásticos, a certeza dos filósofos modernos envolveu uma consciência pungente do problema do relativismo. Ela tinha de ser uma certeza em combate, militante. Um relaxamento momentâneo de vigilância podia custar caro. Algumas vezes custou. (BAUMAN, 2010, p.175).

Ascensão do "intérprete" para Bauman se deu, justamente, quando o relativismo inerente ao discurso e a atitude dos filósofos modernos, em sua batalha contra o que não pode e nem deve exterminar, o irracional, solapa-lhe os espaços. Isto ocorre na medida em que as tantas formas de vida absorvem a concepção modernista de autolegitimação, negando com isto o direito de que um poder judificativo e epistêmico possa, de fora, fundado em um postulado universalista de verdade, investir sobre suas respectivas características e prioridades ${ }^{11}$. No plano discursivo se dão justaposições

respeito à concepção de um "nós" entendido como uma pluralidade de "eus"; a totalidade moral compreende a organicidade de cada eu insubstituível na responsabilidade da sua atitude frente ao outro, mas sem com isto requerer uma simetria assentada na uniformidade diante tanto das ordens dadas quanto daquelas recebidas. Recorrendo a Lévinas, Bauman delineia os contornos do ser moral, primeiro no encontro com o outro, no dado elementar da diferença, da pura assimetria que o encontro revela (BAUMAN, 1997, p, 59-60). Depois, no "nós" que resulta desta assimetria do "ser para o outro" não inscrito em um mandamento universalizável, redunda ser minha responsabilidade "sempre um passo a frente, sempre maior que a do Outro", para o qual tenho a inextrincável certeza de que sua singularidade é o assegurar da minha alteridade.

11. Segundo Bauman, a condição moderna, ao pôr-se o problema de desnaturalizar a ordem, introduziu a humanidade no terreno movediço dos padrões autônomos. Acompanhando a pluralidade de contextos autônomos, mas mutuamente referidos, dotou homens e mulheres da condição de indivíduos. Estes, não estando determinados a princípio por identidades naturais, estiveram (e estão) obrigados ao exercício de construí-las no porvir. A ênfase na escolha deixa patente o fenecimento da rigidez com que os elos coletivos exerciam o controle sobre as condutas. Por outro lado, a proliferação desses contextos normativos trouxe a avaliação para um lugar tão central a ponto de ferir a eficácia silenciosa do hábito. "Uma vez que venha avaliar, porém, fica evidente que o 'útil' não é necessariamente 'bom', ou 'belo' não tem que ser necessariamente 'verdadeiro'. Uma vez que se fez a pergunta sobre os critérios de avaliação, as 'dimensões' da mensuração começam a se ramificar e crescer em direções cada vez mais distantes entre si. 0 'modo certo', uma vez unitário e indivisivel, começa a dividir-se em 'economicamente sensato', 'esteticamente agradável', 'moralmente apropriado'. As ações podem ser certas num sentido, e erradas noutro. Que ação deve ser medida e por que critérios? E se numerosos critérios se aplicam, a qual dar prioridade?" (BAUMAN, 1997, p.09). 
contínuas entre modernistas, pós-modernistas, feministas, pós-colonialistas, deocolonialistas, representantes da teoria queer, entre tantos outros (as). De acordo com Bauman, nenhum campo foi mais sensível a esse deslocamento que aquele das artes; o advento das vertentes estéticas pós-modernistas (GUINSBURG e BARBOSA, 2008) descortinou os impasses puristas herdado das vanguardas modernistas em seus esforços de depurar a arte dos compromissos com os grupos e valores estabelecidos nas hierarquias societárias. Impasses decorrentes da retroalimentação do sistema artístico e a vinculação crescente da obra de arte com os critérios de legalizar, comercializar e realizar lucros, à maneira de outras mercadorias e serviços (BAUMAN, 2010, p.182). Nesse sentido, o fundamento da autenticidade como critério de validação estética estivera cada vez mais corroído pela dinâmica mesma da afırmação da arte como uma forma de vida específica. Enfim, a especialização resulta do curso dos esforços de autonomização frente à intervenção de qualquer fator exógeno à própria cultura.

Para Bauman, o diagnóstico posto pelas vertentes estéticas pós-modernistas pode ser estendido ao conjunto dos ramos intelectuais no Ocidente. No instante em que são reforçadas as autolegitimações das diferentes formas de vida, a prerrogativa dos intelectuais de legislarem sobre a verdade, o julgamento e o gosto em geral deixa de ter pertinência (BAYER, 2008, p.179-398). Ao contrário, deslocados da posição de meta-especialista, eles são, cada vez mais, pressionados a ocuparem o lugar de especialista. E isto, para autor, é particularmente notável na medida em que arte-cultura e mercado se aproximam, tornando-se um mesmo sistema:

Tendo submetido à validação da cultura ao julgamento prático e quantificável da demanda, o mercado reduziu a elite cultural a um dos muitos "grupos de interesse de gosto" a competir uns com os outros pela benevolente atenção do consumidor (BAUMAN, 2010, p.215).

A ironia que anota Bauman está na vicissitude da emancipação da cultura: vimos, sua especialização é fruto desta autonomização, mas esta última, quando faculta um crescente distanciamento em relação ao ordenamento estatal e sua razão civilizatória, depõe contra a possibilidade mesma da república das letras legislar sobre todos os domínios da experiência humana. Inserida no rol sistêmico do mercado e da divisão do trabalho complexa das sociedades contemporâneas, a cultura se encontra destronada do status de fator de integração universal, mas nos limites da interlândia da territorialidade nacional. À luz das formulações de Bourdieu (2009), o sociólogo polonês entende que, imiscuída no mundo comum, ordinário, em que se cruzam ideais e interesses materiais, a cultura conhece profunda ressemantização na qual está referida aos modos como se reproduzem e perpetuam os dispositivos sociais de controle não mais pela disciplina e sim, mediante a sedução ${ }^{12}$.

12. Mais tarde, Bauman irá identificar um “mal-estar” específico à pós-modernidade, distinto daquele concebido por Freud em relação à modernidade (ou ao seu corolário, a "civilização"), em função, justamente, de "os homens e mulheres pós-modernos trocaram um quinhão de suas possibilidades de segurança por 
Nos rastros do que - nos Estados Unidos foi denominado de "virada cultural" ("the cultural turn”) (JAMESON, 2006). Agora, cultura e consumo compreendem um mesmo par institucional e esfera da experiência (FARIAS, 2017, p. 3-14).

A essa altura da argumentação de Bauman, o diagnóstico sobre a especialização da cultura manifesta o cruzamento entre economia e cultura, mercadoria e simbólico, como um forte condicionante na redefinição profunda que ora experimenta a posição social dos/as intelectuais. Alterações essas dispostas no caudal da emergência da estrutura social, destacada pela implicação mútua entre dinâmica capitalista e conversão cibernética do saber em ativo com empregos em planos dos mais diversos da experiência coletiva e individual contemporânea.

Não é o caso de realizar, aqui, uma genealogia do chamado paradigma tecnológico informacional e, por consequência, esca- pa aos nossos propósitos esmiuçar os passos e interpretações que assinalam a ascensão de arranjo societário condizente com esse paradigma. Basta sublinhar que, no início dos anos setenta - do século XX -, o sociólogo Daniel Bell advogava o que chamou de 0 Advento da Sociedade Pós-Industrial. No livro editado em 1973, o autor se propusera tornar inteligível tanto características estruturais quanto padrões de transformações "mais duradouros e coerentes" que revelassem como as relações sociais ingressavam num patamar relacional em dependência da dimensão científico-tecnológica, em um elevado e novo coeficiente. Ainda que as peculiaridades das estruturas sociais nacionais específicas impusessem alterações significativas à apreensão desta dominância, a integração dos elementos estaria em obediência aos fatores técnicos e ao conhecimento especializado. Então, a obra ataca a tarefa de oferecer os limites do conceito

um quinhão de felicidade" (BAUMAN, 1998, p. 10 - em itálico no original). Ou seja, o imperativo moderno da universalidade uniforme, manifesto na atitude do indivíduo de abdicar da própria liberdade de busca do prazer, em nome da ordenação e regulação civilizatória da natureza desordenada e ambivalente, capitularia atualmente ante a "desregulamentação" generalizada, a partir da qual é desenhada a cena "suja" do dia-a-dia pós-moderno. Então, no entendimento do autor, ocorre a dissolução da tendência da sociedade moderna, mediante o projeto de racionalização calcado na aliança entre o arranjo técnico-científıco e o aparato burocrático do Estado-nação moderno, de primeiro identificar para depois, estrategicamente, eliminar o estranho. 0 próprio Bauman, entretanto, coloca aspas na tolerância pós-moderna à diferença. $\mathrm{E}$ demonstra como o imperativo de "pureza” (diferenciação, classificação e unificação) comparece ao círculo das sociabilidades descentradas contemporâneas. Pois se, graças ao impulso infinito às novas sensações, é saudada como liberdade a concorrência entre estilos e padrões de vida e o teste da permanente sedução se abre como a possibilidade de renovação constante, impulsionada pelo mercado consumidor, nem todos são admitidos nos portais dessa convivência ávida de êxtase: "Uma vez que o critério da pureza é a aptidão de participar do jogo consumista, os deixados fora como um "problema", como a "sujeira" que precisa ser removida, são os consumidores falhos - pessoas incapazes de responder aos atrativos do mercado consumidor porque lhes faltam recursos requeridos, pessoas incapazes de serem "indivíduos livres" conforme o senso de "liberdade" definido em função do poder de escolha do consumidor. São eles os novos "impuros", que não se ajustam ao novo esquema de pureza. Encarados a partir da nova perspectiva do mercado consumidor, eles são redundantes - verdadeiros 'objetos fora do lugar”" (BAUMAN, 1998b, p. 24 - em itálico no original). 
de pós-industrial. Porque abrigaria os mais avançados processos nessa direção, os Estados Unidos foram priorizados como unidade empírica para ilustrar o argumento e o formidável montante de dados se refere à descrição de deslocamentos ocorridos naquela sociedade desde a década de 1950.

A tese de Daniel Bell obteve visibilidade ainda em 1962, durante um debate em Boston (nos Estados Unidos) sobre tecnologia. Já naquela oportunidade, o autor deixara patente o seu exercício de previsão, mediante a verificação de índices estatísticos que - concluíra - assinalavam que a estrutura social das sociedades modernas do Ocidente tomava outros rumos, isto em se considerando a organização das suas instituições primordiais, principalmente no que concernia o remanejamento entre estas próprias instituições. Bell se atém no que, para ele, consistia numa mudança de significado a partir da confluência entre ciência e tecnologia sobre o sistema das ocupações. Deste modo, ele descreve a sociedade pós-industrial sob as coordenadas de três processos que se rebatem mutuamente. De um lado, a funcionalização e a burocratização da produção científica de conhecimento, conformando uma arquitetura alveolar de células altamente especializadas, mas complementares. De outro, a maneira de o sistema político responder à tal rotação da estrutura social que se manifestaria na própria acentuação do peso conferido ao componente técnico-científico no que tange à administração da sociedade. Assim, cientistas, engenheiros e tecnocratas rapidamente disputariam com os políticos as rédeas do comando da sociedade. Ora, a terceira ponta do esquema, justamente, no instante que implica na primazia conferida ao conhecimento teórico-cognitivo, compreenderia a diluição do sentido formativo e de aprimo- ramento da cultura, passando à semântica da natureza pragmático-funcional, logo "antinômica" e "anti-institucional".

Para chegar a essas hipóteses, Bell opera com um quadro sinótico de tendências que, sistematizadas, dariam evidências a cinco propriedades básicas da sociedade pós-industrial, ou melhor, suas dimensões elementares. Seriam elas:

1. Setor econômico: a mudança de uma economia de produção de bens para uma de serviços;

2. Distribuição ocupacional: a preeminência da classe profissional e técnica;

3. Princípio axial: a centralidade do conhecimento teórico como fonte de inovação e de formulação política para a sociedade;

4. Orientação futura: o controle da tecnologia e a distribuição tecnológica;

5. Tomada de decisões: a criação de uma nova "tecnologia intelectual". (BELL, 1977, p.27-28);

Está claro que o livro de Daniel Bell evoca, como problemática, o delicado relacionamento entre tecnocracia e política. Uma verdadeira obsessão que dominou as atenções de tantos outros autores que lhes são contemporâneos. A efetivação do modelo fordista keynisiano nas sociedades industriais do Ocidente e do Estado de planejamento nos países do Leste europeu, área de influência da antiga URSS, dispusera esse casamento como um tema candente (ARON, 2002). 0 próprio Bell, no livro 0 fim das ideologias (Bell, 1980), se debruça sobre os limites da política numa estrutura tecnocrática. Em As Contradições Culturais do Capitalismo (BELL, 1980a) o mesmo autor reflete sobre os impasses dos cânones valorativos laboral-produtivista da modernidade, em meio à ascensão da 
tônica depositada no hedonismo próprio ao regime de valores e práticas da sociedade de consumo. E, por isso, a fórmula estrutural-funcionalista do conceito da sociedade pós-industrial contorna as diferenças ideológicas referidas às relações de produção (a questão da propriedade) para reconhecer as semelhanças nas alterações estruturais nos Estados Unidos e na União Soviética. Ambas as sociedades convergiriam - num futuro não tão distante - para um mesmo padrão societário. 0 ponto irônico na avaliação da obra de Bell está no quanto o que há de pífio, falacioso, na sua proposta é, por outro lado, algo sugestivo e mesmo com algum teor de antecipação histórica, embora as expensas da previsão do autor. De concreto, o colosso soviético inclinouse para um sistema societário assemelhado ao norte-americano, porém, tal conversão veio no caudal da insolvência do esquema estatal-socialista e, com isso, a Rússia e suas antigas zonas de interferência foram deslocadas para a economia de mercado. Ao mesmo tempo, a ascensão de uma economia de serviços contatada à hegemonia do conhecimento teórico, consubstanciado num sistema de competências técnico-profissionais, em muito pouco efetivou um potente Estado administrativo de planejamento, capitaneado por uma intelligentsia científico-política.

Enfim, o diagnóstico de Bell revela características de um desenvolvimento que compilou forças e fatores que emularam a favor do elo entre tecnologia, conhecimento e economia como um encadeamento cortante e agudo no potencial transformador das relações sociais, contribuindo na estruturação destas últimas em outro patamar. Contudo, Daniel Bell falava de dentro de um padrão à acumulação capitalista encamisado pelo Estado de bem-estar social.
De acordo com a visão do autor, o computador, como símbolo e artefato da sociedade da informação, da mercantificação do conhecimento, está em muito vinculado à ideia de uma "tecnoestrutura" de instâncias públicas e empresas privadas, contracenando com a centralidade do trabalho regulamentado na organização geral da sociedade industrial.

No ano de 1985, ciente da magnitude que adquiria as tecnologias de informação como força produtiva, mas intuindo seus desdobramentos sobre o âmbito das ocupações e deixando os seus efeitos sobre a solvência do trabalho vivo e, logo, com repercussões políticas e sociais, o pensador polonês Adam Schaff (1995), em um relatório elaborado para o Clube de Roma, sublinhou a emergência de uma "sociedade-informática”. A seu ver, esta titânica alteração na base produtiva teria implicações na direção da recondução a um patamar democrático novo, já não mais condicionado pelo estatuto da propriedade, liberando as pessoas ao ócio criativo da educação e da produção de conhecimento. $\mathrm{Ou}$, ao contrário, à desagregação resultante da eliminação das possibilidades de garantir a sobrevivência devido ao desemprego estrutural, o que poderia fazer recrudescer as lutas de classe e o emprego da força, consumindo recursos em um torvelinho alucinado, culminando em um sistema de opulência, desigual e totalitário calcado na tecnologia de informação - cenário recorrente entre filmes de ficção científica da década de 1980. A seguinte ambiguidade decorre do seu olhar para o futuro: se a microeletrônica poderia provocar o fim da propriedade privada no instante em que teria como eliminar a extração de mais-valia, também poderia comungar contrariamente com a existência da democracia, caso a abolição da apropriação pri- 
vada dos meios de produção tecnológicos fosse consequência de convulsões provocadas por massas desalentadas (SCHAFF, 1995, p.58-59). Daí por que o autor sugere renúncias das classes proprietárias visando a preparar e assegurar às pessoas uma fonte de rendimentos através da previdência pública, com a qual pudessem dispor seu tempo livre na automoldagem como agentes lúdico-criativos.

Ora, é de dentro dessa atmosfera aspirada que se consagrou a expressão "pósmoderno", no final da década de 1970. Nome de relevo naquele momento, o filósofo Jean-Fronçois Lyotard assinalava as dificuldades em manter ajustada a tríade cultura, política e Estado-nação - eixo fundamental à sistemática hegemônica nos dois últimos séculos no planeta. De olho no quanto os aparelhos miniaturizados iam já transformando o acesso, a operação e a classificação do saber, o autor sublinhava a alteração mesma na natureza do conhecimento; segundo ele, por se tornar traduzivel nas tecnologias informacionais, o saber deixava de ser "espírito" e, logo, revertia-se na principal força produtiva. Em termos geopolíticos, os feitos da tendência em curso o leva à seguinte comparação: se antes os Estados nacionais se confrontaram para dominar territórios, doravante iriam aos enfrentamentos na direção do domínio das informações, o que abriria um novo viés para estratégias industriais, militares, comerciais e políticas. Porém, conclui algo um tanto drástico: o próprio Estado tornarse-ia um óbice nesta espiral mercantil do conhecimento (LYOTARD, 1985, p.06). 0 pensador tocava assim no ponto nevrálgico da fase pós-industrial: os novos desafios postos à legitimidade e ao próprio posicionamento dos termos na conexão entre poder e saber, no instante em que sua reflexão indicava a inclinação para o enfraquecimento de algumas das funções até então centrais do Estado-nação. A seu ver, a imagem de sociedade emergente, na correlação do capitalismo com novas tecnologias de informação-comunicação, implicaria em um vínculo mais individualizado por parte das pessoas e, concomitantemente, mais complexo e móvel. Em lugar, portanto, das grandes narrativas legitimadoras (a nação, o socialismo, o humanismo, entre outras), ter-se-iam funções de reprodução e regulagem a cargos de especialistas de todos os tipos, desde que com acesso às informações. As expensas da elite política convencional, eles seriam membros de uma classe dirigente composta de decisores, "dirigentes de empresas, altos funcionários, dirigentes de grandes órgãos profissionais, sindicais, políticos, confessionais.” (LYOTARD, 1985, p. 27). Competência e performance adquiririam, no seu entendimento, o status de chaves à legitimação em um arranjo em que o saber se impõe como poder. Com isto, o autor diagnosticou o desmonte do projeto humboltiano do saber movido à formação espiritual diante do nivelamento do conhecimento em informação processável e performatizada nos circuitos da microeletrônica. As palavras do autor possibilitam concluir que a administração e distribuição dos recursos e a coordenação das relações sociais estariam cada vez mais em sintonia com a economia simbólica. E esta última corresponde à sistemática em que o dueto informação-comunicação condensa nele força produtiva, mercadoria, lógica de interação/classificação e hierarquização dos estratos sociais de tal maneira potente a ponto de afrontar o primado do Estado nacional.

Escrito já na metade final dos anos de 1990, Era da Informação, de Manuel Cas- 
tells, oportuniza outro ponto de vista sociológico acerca do nexo entre tecnologia de informação e relações sociais. Quando, no volume I, Castells mobiliza o conceito de "meios de inovação" para descrever a localização de interações entre sistemas de descobertas e aplicações tecnológicas (ou seja, "o uso de conhecimentos científicos para especificar as vias de se fazerem as coisas de uma maneira reproduzivel"), mostra o quanto a sinergia acionada nesses "meios" é capaz de compactar agrupamentos que se relacionam de maneira retroalimentar em raios de alcance maiores (CASTELLS, 2001, p.55). Assim, o encadeamento descrito por Castells permite relacionar o contexto da sociedade estadunidense, em especial, o âmbito fervilhante libertário de algumas das suas principais universidades - sobretudo aquelas da Califórnia - e o pulsar de iniciativas inovadoras na área da tecnologia informático-comunicacional, no decorrer dos anos setenta. No entendimento de Castells, a emergência deste sistema tecnológico, naquela década, nos Estados Unidos, precisa ser compreendido pela combinação entre a descoberta e a difusão tecnológica, tendo efeitos sinérgicos sobre o conjunto das demais tecnologias (CASTELLS, 2001, p.65). Ao mesmo tempo, assinala que a disponibilidade deste manancial tecnológico se tornou básica à reestruturação socioeconômica dos últimos anos oitenta. Para ele, é apenas na interação entre as tendências autônomas - ou seja, do desenvolvimento de novas tecnologias da informação e a tentativa da antiga sociedade em se reaparelhar - que a "sociedade de redes" se viabilizará (CASTELLS, 2001, p.69). Deflagrou-se, assim, o desenvolvimento que dotou estas novas tecnologias da característica de aplicação de conhecimentos e informações para geração de conhecimentos e dispositivos de processamento/comunicação da informação (CASTELLS, 2001, p.50-51).

Para Castells, apesar da diferença entre as experiências nacionais, em todos os casos a aceleração do desenvolvimento tecnológico contou com o decisivo estímulo dos seus respectivos Estados nacionais ou fomentando as pesquisas, mediante a dotação de verbas previstas em seus orçamentos, ou fazendo encomendas à iniciativa privada especializada do setor. 0 que leva Castells, portanto, a inferir que esse avanço se deu na correlação com macroprogramas de pesquisa e grandes mercados fermentados pelos respectivos governos nacionais, mas lastreada na inovação descentralizada, cujo estímulo advém de uma cultura de "criatividade tecnológica” e por fulgurantes sucessos pessoais. Para o autor desta rede, agrupando circuito de empresas, organizações e instituições estatais, se forma um novo paradigma sociotécnico (CASTELLS, 2001, p.77). 0 paradigma sociotécnico informacional está pautado, predominantemente, segundo a descrição do sociólogo espanhol, nos insumos baratos de informação, devido ao incremento tecnológico na microeletrônica e nas telecomunicações. Sua matéria-prima são tecnologias com as quais se age sobre a informação, e se faz prosperar a lógica das redes, em sua característica flexível e complexa, isto graças ao poder de penetrabilidade desse aparato tecnológico e de sua capacidade de reconfıguração. Isto é, são as redes dotadas de uma abertura a acessos múltiplos, nos quais prevalecem processos contínuos de "ações deliberadas e interações exclusivas, que alteram normações” (CASTELLS, 2001, p.81). E nesse sentido que o paradigma tecnológico informacional incide de maneira crucial nas rotações estruturais mais abrangentes nas relações sociais, afınal, a capacidade do sistema de redes em fisgar o conjunto das informações e tornar estas úl- 
timas partes de um mesmo sistema, operando com velocidade maior, na contrapartida de custos menores, terá impactos indeléveis em várias dimensões da vida humana, principalmente no eixo econômico-financeiro. Mas, de um modo geral, seu potencial está definido pelas articulações inéditas que permitem entre a criação e manipulação de símbolos e como pode capacitar a ativação de produção e distribuição de bens e serviços, constituindo-se numa formidável força produtiva (CASTELLS, 2001, p.51).

Nesse cenário de ascensão da imaterialidade como fator estruturante das relações sociais, desdobra-se o processo aqui denominado de informacionalização das expressões. Lançamos mão, a princípio, da maneira como Pierre Lévy (1993) concebe a tendência arrolada desde o século XV, no Ocidente europeu, na qual materialidades são reprocessadas em esquemas técnicos básicos à confecção de roteiros, mapas, planos, tabelas e horários. Movimento mais tarde acelerado com o advento das tecnologias de reprodução do simbólico e de ampliação do raio de alcance da comunicação por diferentes códigos e linguagens - sonoros, visuais e audiovisuais. Ou seja, tal tendência é definida pela aplicação de fórmulas fundamentadas na matemática com o objetivo de simular e daí controlar virtualmente a produção das próprias materialidades. Compreende propriamente a informacionalização das expressões a inserção, entre o leque de possibilidades expressivas, daquela envolvendo um regime de modelação dos humores corpóreos - intrínseco à formação das disposições humanas - em que tanto a percepção da autoimagem quanto do reconhecimento pelo outro são mediados pela centralidade da possibilidade de se tornar objeto não apenas da contemplação alheia, mas, sobretudo, de replicação técnica digi- talizada de si. Logo, o processo abrange a construção da subjetividade e também dos laços interativos, mas se realiza na medida em que são acionados dispositivos de aprendizado pelos quais a competência simbólica do agente humano se efetiva em gestos e sons mediante um tipo de reprodução e recriação de modelos de autocontrole gerados no escopo da engrenagem sintonizando meios técnicos de produção e reprodução de imagens, gêneros, estilos e linguagens de exposição, todos vinculados ao universo da comunicação social ampliada. Diríamos, enfım, que a informação se torna estrutural aos agenciamentos.

Nesse sentido, adotamos aqui a designação estrutura urbano-industrial e de serviços, e o emprego obedece a dois propósitos. 0 primeiro de natureza morfológica. Para detalhá-lo, recorrerei ao vocabulário estrutural-funcionalista. Sabemos que o conceito de estrutura social compreende a referência aos limites de um sistema social. Quer dizer, abrange o padrão de inclusão/exclusão e coordenação dos elementos qualificados como componentes funcionais à dinâmica de reposição da própria sistemática em meio à sucessão de episódios histórico e cósmicos. Deste modo, podemos falar desses limites como a priori espaço-temporais cujos matizes de escalas poderão tanto deflagrar ritmos em seus protocolos de rotinas à condução dos atos quanto serem ritualizados posicionamentos em graus estratificados de institucionalização. Mas, esta primeira caracterização se aprimora, para reiterar a concepção de Giddens (1989, p.86), ao podermos remanejar o enunciado acima e tomar a estrutura como recurso capacitado (por estar autorizado) a emoldurar a posição e reposição (equivalendo à recursividade reflexiva como também o desempenho dos/as agentes) das linhas de condutas definidoras 
de um sistema social. Algo assim facilita o trabalho do analista comprometido com o estudo processual em sua odisseia de figuras. Facilita na medida em que exige do intérprete rastrear e justificar aquilo por ele eleito enquanto recurso estrutural no escopo de determinada condição histórico-social, obrigando-o a qualificar processualmente a própria condição (claro, e ele próprio como sujeito reflexivo dessa objetivação).

Relativo ainda a esse aspecto, o outro plano que chama atenção é a semântica da ideia mesma de estrutura urbano-industrial e de serviços. Quer-se ressaltar com a denominação uma tipologia societária na qual a instrumentalização avança para além da intervenção humana na natureza, isto é, vai adiante da formatação dessa última em matéria-prima obediente à lógica produtivista e desenvolvimentista industrial-capitalista da modernidade. Com o emprego da categoria se trata, sim, sem advogar uma ruptura com essa lógica, da iniciativa de destacar a condição em que adquirem status as cadeias de formulação e processamentos responsáveis pela qualificação de algo em um bem. Enfım, ganha importância teórico -analítica os complexos técnico-cognitivos nos quais a otimização dos estoques de conhecimentos e suas mediações - a informação, enquanto fluxos binários de comandos (GLEICK, 2011) - protagonizam o incremento da produção e reprodução tanto nas dimensões materiais quanto intangíveis, e sob a égide da orientação monetário-financeira. Logo, a dinâmica de permuta e equivalência entre signos (e, portanto, não entre signos e coisas) se insere crucialmente na vitalidade do capital e esta, por sua vez, enraíza-se nos âmbitos da diversidade bioético-societal, definindo a condição contemporânea (FARIAS, 2010, p. 11-40).

Para os objetivos deste dossiê, pelos vín- culos diretos com a cultura letrada, as alterações ora em vigência nas estruturas e dinâmicas do mundo editorial são emblemáticas. Com o advento da chamada "revolução digital”, a cadeia composta por autores, editores, empresários editoriais, revisores, diagramadores, gráficas, designer, divulgadores, publicitários, livreiros, críticos e usuários é revolvida, em particular porque se dá a desnaturalização do nexo entre texto e o suporte próprio à mídia livro. Se, de um lado, verifica-se a pluralização das fontes de concepção e produção textual, pressionando os regimes autorais e os protocolos jurídicos das patentes intelectuais, de outro, a instalação de imensos conglomerados empresários, resultantes de fusões entre empresas em escala global, desloca e instaura posições e funções dentro dessa cadeia, a exemplo do agente literário como corretor. A transnacionalização do capitalismo editorial, em dueto com a expansão planetária das grandes redes varejistas, por sua vez, estabelece níveis inéditos pela alta proporção de concentração dos meios de curadoria e circulação/divulgação de bens editoriais. Contracenando com a hegemonia político-militar e cultural-midiática dos Estados Unidos, a indústria editorial anglófona impõe-se às demais concorrentes (THOMPSON, 2013), domínio este posto no reverso da crescente consagração do inglês como língua franca, nos mais diversos âmbitos (corporativos, acadêmicos, turísticos, do marketing, da publicidade, etc.) constituintes do mercado linguístico global (ORTIZ, 2008).

0 atual cenário da indústria editorial articula-se à emergência de modos de simbolização e de circulação dos conhecimentos e da culturas, mediante as teias das ecologias sociotécnicas informacionais, com efeitos na definição tanto de outras instâncias de legitimação/visibilidade da produção do 
trabalho intelectual quanto de multiplicação dos perfis dos agentes intelectuais, cada vez mais especializados como "produtores de bens culturais"13. Somadas às participações em noticiosos, talkshows e programas de debate em TVs, com a proliferação das redes sociais (Facebook, Twitter, WhatsApp), ao lado de plataformas de vídeos (YouTube, por exemplo), além do recurso aos blogs, o fornecimento e acesso a conteúdos simbólicos digitalizados pressionam no sentido da ampliação e diversificação, mas também de maior compartimentação/especialização dos exercícios intelectuais de tradução e conceituação dos ingredientes sociopsíquicos de formação da consciência. Vê, portanto, um outro patamar na relação entre habilidades, prestígio e fontes de financiamento no tangente à probabilidade de que o agir reconhecido como intelectual tenha repercussão nas circunstâncias dos seu acontecer. Af1nal, se a concretização dessa probabilidade está submetida à natureza e o valor conferido aos meios de expressão e comunicação, ora assistimos um aumento de volume e de qualidades das práticas intelectuais, porém estas se veem sobremaneira condicionadas aos trâmites e protocolos nos quais interagem capitalismo cultural, paradigma informacional e linguagem digital ${ }^{14}$.

13. Ao acompanhar a circulação cultural e dos saberes, Andréa Borges Leão tem sido especialmente feliz em encontrar emblemas desses deslocamentos contemporâneos. Em "Fazer do velho uma novidade. As reinvenções dos best-sellers juvenis” (LEÃO, 2017, p.463-474), a autora dá prosseguimento às suas pesquisas acerca da montagem das interdependências sociofuncionais do espaço literário transnacional. Dessa vez, a autora se debruça ante o regime de historicidade próprio à formação dos best-sellers infanto-juvenis, na medida mesma em que desconfia da certeza que marca a classificação e a compreensão sociológica consagrada sobre esse gênero literário. Para essa última, o único critério de legitimação desse bem simbólico é o êxito comercial, já que ele não atende a quaisquer dos critérios de avaliação de qualidade cujos guardiões se aninham entre as determinações espaciais e temporais que, desde o século XIX, articulam a Europa Ocidental, em especial França e Inglaterra, e as Américas pelos trânsitos de ideias, técnicas, editores, livreiros, etc., na conformação da teia que envolve autores, textos e leitores dessa literatura infanto-juvenil. Percursos cruciais, inclusive, aos destinos da emergência e consolidação de diferentes literaturas nacionais nos dois continentes. Na sua face atual, a mesma trama transatlântica se manifesta no reposicionamento do Brasil: de importador a produtor ou exportador desses best-sellers. Borges Leão focaliza uma das protagonistas de tal circuito internacionalizado da cultura, a jovem escritora carioca Thalita Rebouças. 0 exercício etnográfico realizado pela socióloga permite constatar que, afastando-se dos cânones da arte simbólica estabelecidos pela crítica romântica alemã, na definição do literário, ainda no século XIX, essa nova geração de autores e autoras deixa ver um sistema literário no qual o regime de autoria e aquele de visibilidade se confundem com a perspectiva de que obra literária e mercadoria não são porções disjuntivas, mesmo antagônicas entre si. Observa Borges Leão, porém: não se trata apenas da postura modernista de apreço pelo "novo"; a cumplicidade com o "antigo" se dá em razão da atualização de formulas editoriais consolidadas - contos de fada, por exemplo. Nesse instante, apropriando-se da modelagem eliasiana e das fórmulas de Cas Wouters sobre informalização do comportamento, característica da atual economia pulsional, a autora destaca as regras e etiquetas internas ao esquema narrativo das obras, as quais ocupam espaço estratégico como dispositivos de refreios de afetos no movimento pelo qual promove a formação do autocontrole de emoções. 14. Esta complexa rede de interdependências sociofuncionais é considerada no artigo " 0 discurso do marketing de lugar e os grandes eventos: investigação sobre artífices de um senso comum planetário”. Nesse texto, Michel Nicolau Netto (2017, p.495-511) leva em conta a cada vez mais relevante posição 
0 esforço no sentido de traçar constelações socioestruturais responde ao interesse de interpretar as maneiras como modalidades de compreensão humanas ganham vigência, na medida mesma em que os/as agentes incorporam a questão da historicidade do tempo e da mudança como fatores preponderantes à continuidade e o reciclar das suas experiências e memórias, algo este tecido pelas interdependências e interpenetrações sociofuncionais que ensejam coalescências de carências socialmente significativas e instauradas no universo simbólico e no plano das linguagens socialmente mobilizadas. Nesse sentido, ao se considerar a posição estratégica ocupada pelos(as) intelectuais na decantação simbólica dos modos de compreensão humana, o olhar lançado neste dossiê está em grande medida movido pela curiosidade em relação às incorporações dos condicionantes socioestruturais contemporâneos relativos à convergência entre especialização da cultura e paradigma tecnológico informacional digital-cibernético nas maneiras mesmas como as funções intelectuais são exercidas, autorizadas e adquirem visibilidade nas trocas públicas de sentido. Se não se trata de fazer vaticínios como o "fım" dos intelectuais (BOBBIO, 1997), tampouco reclamar do seu silêncio (Novaes, 2006), a multiplicação das semânticas de aplicação desse termo de nomeação tão prestigiado traz a reboque dúvidas concernentes não só na identificação das instâncias de legitimação e dos meios de visibilidade dessas práticas, mas coloca em xeque o núcleo do que se percebe e categoriza como fazer/ser intelectual (MAT0, 2004). Enfim, na atualidade, há uma espécie de torpor deixando em suspenso o estofo ontológico pelo qual se ergueu essa posição de sujeito.

Em se tratando da América Latina (ALTAMIRANO e MYERS, 2008; RAMA, 2015; IANNI, 2012), mas em particular, do Brasil, sobressai o vínculo secular entre inte-

cultural, econômica e política do circuito de grandes eventos, para se ocupar da modalidade específica de mediação exercida no mundo contemporâneo pelos profissionais do setor de marketing que atuam em escala global. Isso pelo fato de eles estarem aplicados à produção discursiva em que se tecem os sentidos que ressignificam lugares como espaços nos quais se fazem visiveis algumas das figuras da globalização. Desse modo, o autor focaliza o trânsito acionado por esses artífices entre traços sedimentados como expressivos de identidades sociais e a lógica publicitária no emprego de marcas com a finalidade de posicionar bens nos mercados. 0 artigo se aplica à análise dos efeitos práticos vinculados à discursividade na qual se estabelece a homologia entre as ideias de mundo e de mercado, a qual adquire a envergadura de um senso comum planetário. Nesse sentido, ao se ater às propriedades das narrativas que identificam e vocalizam hipotéticas vocações de lugares para sediar grandes eventos, a análise do discurso empreendida articula os nichos em que se posicionam as falas peritas dos profissionais do marketing às diversas entidades políticas (Estados nacionais, por exemplo), econômicas (corporações privadas transnacionais) e representativas de sistemas esportivos, artístico-musicais, de moda e outros. Assim, não apenas procura objetivar sociologicamente os contextos de produção e circulação desses sentidos; em especial, interessa sublinhar a emergência de novas instâncias de visibilização de bens culturais que consagram, conferindolhes legitimidade tanto na agenda dos grandes eventos como no próprio discurso publicitário. E, nessas instâncias, embora não estejam confundidos, simbólico, político e econômico transitam entre si, tornando cúmplices prestígio e lucro financeiro. 
lectuais e a questão da nacional (ORTIZ, 1984; PÉCAUT, 1990; MICELI, 2001). E, por meio desta última, aproximando-se do engajamento com o temas tendo por núcleo as experiência e condição de modernidade brasileira (TAVOLAR0, 2005, p.5-22). Além das problematizações a respeito do desenvolvimento socioeconômico, da consolidação de um Estado democrático direito e da identidade nacional, são representativos desses temas os conflitos entre as classes sociais e os impactos étnico-raciais da escravidão numa sociedade movida pelo esforço de modernização (FERNANDES, 2008). Logo, a modulação ontológica da posição/função do intelectual revolve um terreno que, ao longo de todo século passado, esteve cimentado por obter respostas sobre os efeitos nesse fazer enraizado na condição de dependência socioeconômica de uma sociedade periférica no escopo do capitalismo internacional, de acordo com Antônio Candido (1997). Muito embora tal condição permaneça vigente, os complicadores na busca dessas respostas lidam agora com os impasses vindos a galope dos efeitos da especialização da cultura disposta na dinâmica da economia simbólica à contrapartida do amplo e heterogêneo raio de alcance da sociedade de consumidores e da estrutura urbano-industrial e de serviços no país. Apenas para assinalar alguns desses aspectos, de maneira sumária, focalizaremos quatro entre eles; o relevo político adquirido pelas identidades coletivas num espaço público segmentado e de disputas acirradas, que leva à tona uma gramática moral calcada nas terapias comunicativas orientadas ao desmonte dos racismos, sexismo, homofobias, etc., às quais estão manifestadas nas políticas de significados, e não somente regionalizam as pretensões de formações discursivas como a dos direi- tos humanos, como também verberam insulamentos socioculturais que tanto ratificam quanto promovem gestos intolerantes de diferentes ordens (BOSCO, 2017). Já a midiatização da imagem pública e do saber (SARLO, 2004; 1997), ao mesmo tempo que favorece a pluralização dos pontos de vista, deixando em xeque as certezas ortodoxas favoráveis a facções sociais estreitas, promove uma espécie de neosofismo em que a disputa incessante e cruenta das opiniões se levanta como obstáculos à montagem de consensos negociados a partir do confronto dos argumentos em torno de fundamentos a princípio indiscutidos. Na contramão desse silenciamento, a execução de estratégias de visibilidade das imagens pessoais subordina as ideias à lógica social da celebridade (ORTIZ, 2016, p.669-697). No compasso da intensidade obtida pela circulação global do conhecimento, a especialização/profissionalização acadêmica responde à sincronia do sistema universitário brasileiro aos esquemas dos mercados universitários e científıcos mundiais, cujos desígnios requisitam uma codificação do pensamento e da linguagem a agendas temáticas e fórmulas expressivas sintonizadas com audiências amplas, porém culturalmente diversificadas a serem equacionadas por critérios de objetividade de escrita que evitem a polissemia (MARGATO e GOMES, 2004; BIANCHETTI, 2015). As controvérsias em torno de poder à autoridade com pretensões universais do saber letrado e com respaldo no sistema escolar formalizado, exercido por peritos, legislar sobre àqueles outros assentados no costume e na oralidade, com forte presença das marcas corporais (étnico-raciais, gênero, sexual, classe e tantas outras), identificados a povos reconhecidos como "tradicionais” e/ou a grupos estigmatizados, acentuam os limites da própria pretensão 
da epistemologia universalista, flagrando -a igualmente enraizada em territorialidades cultural-hermenêuticas específicas (DA CUNHA, 2007, p.76-84; TAYLOR, 2000).

Sem buscar qualquer consenso ante essa problemática ontológica, decorrente da especialização do intelectual no escopo da cultura contemporânea, cada um dos seis artigos que compõem este dossiê investe num complicador específico, não em obediência à finalidade de ratificar incertezas; aos moldes do poeta-adivinho benjaminiano (GAGNEBIN, 2002, p. 125-133) ou do historiador indiciário de Ginzburg (2017), os/as autores/as apostam nos sinais, naqueles rastros cujas silhuetas incitam avançar sobre tendências sócio-históricas e existenciais das quais os/as intelectuais são, a um só tempo, decantadores(as) e individualizações, logo intrínsecas às singularidades subjetivas e aos seus círculos de interação, mas atravessados em suas pulsões psíquicas pelas determinações socioestruturais contemporâneas.

No movimento da sua argumentação, em "Ciências Sociais e Ética: sobre o respeito aos outros saberes", professora da Universidade Humberto Hurtado, em Santiago (Chile), a antropóloga Francisca Márquez toca num ponto nevrálgico ao pensamento e à produção do conhecimento no mundo contemporâneo: o diálogo das disciplinas socioantropológicas com a ampla e multifacetada polifonia étnico-histórica num tempo em que estas últimas se recusam a estarem reduzidas a objetos para os exercícios cognitivos e morais dos legisladores inscritos nos campos do saber social. $\mathrm{Ou}$ seja, a tão assonante recusa diz respeito ao silenciamento da dignidade dessas formas de vida quanto à própria capacidade de se autonomearem, de apresentarem versões singulares da experiência humana e das texturas ambientais em que se inscrevem. 0 problema ético suscitado coloca em tela os debates políticos e intelectuais acerca do reconhecimento dos limites por parte da posição discursiva acadêmico-intelectual acostumada, na medida mesma em que se autopercebe neutra, esquecer do quão é posicionada em relação a outras posições sociais, para logo evocar sua universalidade, reduzindo os seus congêneres a particularidades culturais. Mas a autora estende a recusa, afınal, cobra dessas manifestações da diversidade sociocultural evitarem o silêncio em relação às condições socioestruturais dessa interlocução. Contracenando com a teoria do poder simbólico de Pierre Bourdieu, a antropóloga reclama uma postura ético-cognitiva que politize os tramados das posições no campo dos saberes sócio-humanos, isto, no instante em que avance para além das disputas no mercado concorrencial das epistemologias. Diante dessa finalidade, Márquez potencializa sua inserção no espaço acadêmico das Ciências Sociais chilenas - tardia em relação ao conjunto da América Latina, em se tratando da problematização dos impasses e dilemas relativos às fraturas e clivagens inerentes à formação nacional e do povo-nação. Atenta aos próprios condicionantes socioestruturais que a atravessam, constituídas suas possibilidades discursivas, a autora ratifica o reconhecimento da posição de sujeito de voz e judificação para indígenas, jovens, desalentados de desastres socioambientais, entre outras faces dos atuais movimentos sociais ascendentes nos domínios de públicos de visibilidade. Assim, requisita a escuta dos diversos saberes mediante uma chave não restrita ao esquema da documentação subordinado à lógica do arquivamento acadêmico. Leva-nos (a nós, leitores[as]), à percepção do tema da desigualdade no pla- 
no silencioso das formas de expressão, da estratificação hierárquica estabelecida entre as escrituras do conhecimento. Porque, se a triangulação memórias, histórias e conhecimentos tece um mesmo denominador para as culturas, o fulcro do corpo vivo se mantém recalcado em razão do status de universal concedido para o registro escrito alfabético e numérico, ainda que este permaneça muito aquém do alcance de modos de experiência e simbolização cujas escritas são apresentações simultâneas às oscilações, deslocamentos e metamorfoses corporais.

Assinado por Frederico Barbosa e Mariella Pitombo, o artigo "A Linguagem da Paixão: intelectuais e políticas culturais no Brasil”, traz para o debate uma das vicissitudes atuais do amplo reescalonamento dos Estados nacionais à medida que as políticas de significados e o direito à cultura redimensionam as semânticas do Estado Democrático de Direito. A saber, o delineamento das pesquisas, estudos e reflexões sobre as políticas públicas culturais na condição de um campo de conhecimento alocado no âmbito acadêmico-universitário. Por certo, a experiência francesa, instaurada com o advento do Ministério da Cultura, em 1959, ressoou e ainda permanece repercutindo em partes distintas do sistema internacional, mas em particular na América Latina, a qual já contava com as antecipações dos governos pós-revolucionários mexicanos. Os efeitos da promulgação do texto constitucional, em 1988, conferiu certa sistematicidade para o caso brasileiro - objeto de atenção do artigo, pois incluiu a cidadania cultural entre os parâmetros de uma sociedade às voltas com a tentativa de se reencontrar com a democracia. Interessalhes, em particular, o período iniciado em 2003. Devido ao fato de muitos dos seus integrantes de primeira hora saírem das fileiras da esquerda no país, o cenário político-institucional posto no caudal da chegada do Partidos dos Trabalhadores ao governo federal, argumentam os autores, teve decisivo papel na montagem da Rede Cult - foco analítico do texto. Tendo por sede a Universidade Federal da Bahia, o grupo capitaneado por Albino Canela Rubim (posteriormente, chefe da pasta da cultura durante a administração de Jacques Wagner, no governo estadual baiano) ocupa espaço no domínio das discussões acadêmicas sobre as políticas públicas culturais, no compasso mesmo do revestimento de prestígio intelectual à institucionalização dessa arena no país, com os seus circuitos, fóruns e agentes. Tomando as rédeas da proposição de eventos, da condução de publicações, instalando um programa de pós-graduação na área de produção e gestão cultural, na última década, os representantes da Rede Cult - muitos dos quais articulados às engrenagens governistas nos níveis locais, regionais e federais - fixaram agendas tanto de avaliação quanto de formulação intelectual a respeito das políticas públicas culturais. Notam os dois autores que, no cômputo geral da conjunto produzido pelo grupo, sobressai a defesa consensual da postura pós-neoliberalista para a atuação do Estado, tornando evidente um modelo de pensamento com claras implicações normativistas. Em lugar da opção por fazerem-se de geômetras (usando o vocabulário conceitual interno ao artigo), o personagem por excelência do credo racionalista platônico e, depois recuperado pelo eu epistêmico cartesiano, como se olhassem de cima e distantes, Barbosa e Pitombo perscrutam o lugar mesmo do qual se manifestam para se lançarem à tarefa de descrever, analisar e conceituar a Rede Cult. Deste modo, a argu- 
mentação desenvolvida no texto compartilha com o artigo anterior o caminho acertado de refletir sobre os limites da Sociologia de fazer visível a trama das relações sociais. Para isso, consideraram o tenso equilíbrio de uma epistemologia comprometida com a verdade resultante do controle teórico-empírico das proposições e o encontro desta, na produção de conhecimentos, com as prerrogativas de diferentes moralidades, sabendo-se que não está em jogo tão somente fazer o julgamento pleno em lisuras dessas últimas, porque os agentes socioantropológicos não estão isentos de moral e interesses. Seres apaixonados, logo incompletos, compostos pelos afetos das redes de dependências e pressões mútuas em que se encontram, igualmente, são delimitados no alcance das suas objetivações.

Intérpretes à maneira de Renato Ortiz (1992), Roger Chartier (1995, p. 179-192) e Peter Burke (2010) sublinharam a origem erudita da categoria de cultura popular e sua propagação no compasso tanto da centralização promovida pelos Estados nacionais quanto o estabelecimento das estruturas urbano-industriais com efeitos indeléveis na requalificação de grupos sócio-humanos. Outros, como Adam Kupper (1988), enxergam na ideia de cultura popular uma versão, para uso doméstico, do mesmo ímpeto de anacronização de modos de vida aplicados aos povos "sem história" (WOLF, 2005) pelo colonizador europeu, ao se fazer uso do conceito de "sociedade primitiva”. 0 emprego da ideia de cultura popular evidencia, portanto, o desempenho legislativo próprio ao poder de nomeação a cargo de facções intelectuais, categorizando práticas, símbolos e formas humanas de vida. Sem descuidar dessa faceta de dominação simbólica, em "Os Intelectuais e a Cultura Popular em São Paulo: do fol- clore às políticas culturais", Celeste Mira e Vera Lúcia Cardim de Cerqueira optam por considerar as mediações de intelectuais em três momentos significativos da história das formações étnico-históricas abarcadas pela denominação cultural popular, na experiência paulistana. Inscrita num intervalo de quase cem anos, a argumentação desenvolvida no artigo alcança o projeto de Mário de Andrade, entre as décadas de 1920 e 1930, com todo o empenho deste erudito não apenas de mapear, catalogando as múltiplas manifestações populares brasileiras algo realizado por meio de suas "missões" pelo Norte e Nordeste do país -, mas alocá -las na dimensão artístico-cultural. Com a troca de sinais e status, ele almejava favorecer a inserção da cultura popular no acervo patrimonial da nação e, com isto, atrair o cuidado por parte de ações executadas pelos representantes estatais. Fundado em 1935, o Departamento de Cultura da cidade de São Paulo, sem dúvida, é o marco na administração pública no Brasil. Neste órgão municipal, Andrade idealizou e pôs em prática alguns dos seus projetos, tendo por objeto a cultura do povo. Em um segundo momento, as autoras focalizam um dos desdobramentos dessa atuação do literato modernista, na cidade: o braço paulista do Movimento Folclorista Brasileiro. A atenção se volta, em especial, para o nome de Rossini Tavares de Lima, eleito presidente da Comissão Paulista de Folclore e cujo feito maior esteve em integrar manifestações da cultura popular regional às comemorações do IV Centenário de São Paulo. Já o terceiro estágio na exposição e análise traz a intervenção de um dos alunos do curso sobre folclore ministrado por Tavares de Lima, já na década de 1980: o autor e diretor de teatro Antonio Teixeira de Macedo, responsável pela criação do grupo cultural Aba- 
çaí, nos anos de 1990; grupo decisivo em se tratando de uma matriz de apropriações simbólicas de artesanais, músico-percussivas e artesanais, entre extrações de classes médias urbanas, em meio à replicação de grupos afıns, atraindo em particular jovens com níveis mais elevados de escolaridade formal. 0 percurso levado a cabo por Mira e Cerqueira deixa entrever os rastros das mediações exercidas por esses intelectuais, fomentando públicos dos quais saíram continuadores; estes se firmam espécies de herdeiros que, normalizando a cultura popular, a inserta no quadro de políticas públicas, num momento que o horizonte hermenêutico-normativo da diversidade cultural repercutiu também nas agendas do Estado brasileiro na última década. Ao mesmo tempo, porém, igual trajetória identifica os limites de tais atuações, considerando-se a recorrente precariedade quanto ao financiamento dos agenciamentos pessoas e institucionais da cultura popular, ao lado da incapacidade de se autonomear sem fazer recurso ao pensamento erudito.

Uma vez mais, a trama das interdependências sociofuncionais é ressaltada no tocante ao exercício de mediações por segmentos intelectuais, mas agora colocando em destaque as implicações entre artistas e críticos de arte. No artigo "Centro e Periferia na Produção e Avaliação da Obra de Gilvan Samico”, Eduardo Dimitrov se volta ao trânsito desse artista plástico pernambucano no percurso que o levou do recifense Ateliê Coletivo, no qual lhe foi impresso os primeiros conhecimentos sobre gravuras com Aberlado da Hora, até São Paulo, de onde se deslocou para o Rio de Janeiro e, de lá, fez o caminho de volta a Olinda. Portanto, o debate sobre a circulação cultural informa a análise, mas o autor o faz entretendo os dois seguintes planos analíticos: de um lado, o percurso de Samico referido aos seus diferentes diálogos com nomes consagrados do campo artístico brasileiro, na sua clave modernista, à maneira de Lívio Abramo e Goeldi; de outro, a circularidade é retomada sob a perspectiva das aproximações entre o erudito e o popular. Dimitrov persegue esse último aspecto auscultando à ascendência do Movimento Armorial, mais especificamente Ariano, espraiando-se dos domínios pernambucanos às instâncias de classificação e consagração dos bens simbólicos no país. De olho na pressão exercida sobre a conversão nos modos de perceber os objetos artísticos e os artistas, interessa-lhe a cumplicidade estabelecida entre as prescrições de Suassuna sobre os itens que definiriam uma gravura nordestina, popular-nacional, e às rotações no fazer de Gilvan Samico, esforçando-se no sentido de deixar para trás as influências em termos de escolhas de motivos pictóricos, adoção de paleta de cores, procedimentos e técnicas "alienígenas" herdadas durante o estágio no Sudeste brasileiro. 0 traço perspicaz da interpretação do autor está em colocar em suspenso a pretensa conversão do gravador a um regionalismo autorreferido, capaz de subsumir as hierarquias e desproporções de recursos simbólicos e financeiros que atravessam, perfazendo os lugares da criação, da crítica e da recepção. Fazendo uso criativo das categorias de "semelhança forçada" ou de “difusão enquanto conflito", tomadas de empréstimo do teórico da literatura Franco Moretti (2003), ele rastreia na caminhada do artista a naturalização das categorias e esquemas eruditos que circulam do centro nacional - lembrando ser este um polo periférico no mapa da arte internacional, à luz da centralidade europeia e estadunidense ao Nordeste, inclusive, respaldando confli- 
tivamente uma essência local/regional. $\mathrm{Na}$ contramão da tônica depositada no valor do autêntico, comum ao discursivo ideológico da região e/ou nação, a cartografia geopolítica realizada por Dimitrov deixa por saldo a possibilidade de objetivar mais que o entrelaço desigual e discrepante no acesso aos meios de nomeação e afirmação expressiva das posições-funções no espaço de possíveis artístico; sobretudo, como essas características dessa constelação de posições estão materializadas nos corpos dos objetos, críticos e criadores.

Em comum com o artigo anterior "Poder, Sexo e Línguas no Marxismo à Brasileira”, debruça ante o problema da posiçãofunção, levando em conta a perspectiva da circulação internacional, no caso de ideias. A inspiração teórico-analítica bourdieusiana para tratar do tema manifesta-se na atenção dada às condições locais de recepção e uso de uma fortuna intelectual. Com isso, assinado por Lidiane Rodrigues, o texto contém elementos muito sugestivos à sociologia da ciência e do conhecimento dedicado a um dos caminhos intrigantes tomados pelo desenvolvimento do campo do pensamento social no Brasil: a alocação das diferentes linhagens marxistas dentro do meio universitário. Afinal, Rodrigues revolve o problema de maneira original no instante em que opta por atentar aos diferentes rendimentos em termos do retorno simbólico para os investimentos em instrumentos cognitivos e de expressão-comunicação, no tocante à inserção no espaço acadêmico feitos pelos diferentes agentes. Recorre, justamente, à equação da confluência entre o valor de diferenciação oferecido pelo domínio/emprego de um idioma e à montagem de um mercado acadêmico das humanidades no país. Os fatores socioestruturais decisivos às peculiaridades da capital paulista, na passagem das décadas de 1950 e 1960, isto é, a dinâmica de metropolização/industrialização se decalvava na estratificação social, mas estava transfigurada na Faculdade de Filosofia, Letras e Ciências Humanas da Universidade de São Paulo (FFLCH/USP). Eis o locus do qual parte a autora, focando os grupos surgidos com a finalidade de ler 0 Capital (de Marx). Os episódios se mostram de fato heurísticos, porque os encontros e enlaces aproximaram mestres e estudantes e, assim, diferentes trajetórias - homens maduros e jovens, representantes de facções tradicionais e de famílias em mobilidade social, nativos e filhos de imigrantes, etc. - se inscreveram em disputas a princípio restritas às lutas escolásticas, cujo objeto seria a preponderância no mundo dos bens espirituais. Assim, o tecido narrativo do artigo desvela as condições institucionais numa conjuntura em que há o predomínio da filosofia e, com este, o prestígio conferido aos falantes de alemão nos círculos de marxistas, que fez dueto com a expansão da universidade pública, refúgio desses mesmos grupos no período da ditadura militar mais ainda. Inicialmente sugerida, a estratégia de inferência morfológica, adiante, permite tirar consequências analíticas bem mais proveitosas, pois o recurso à categoria de população permite não só alcançar o aumento progressivo das linhagens marxistas, mas também a diferenciação interna ao conjunto dessas mesmas extrações com suas desproporções em termos da distribuição de recursos e, portanto, com distintos efeitos de posicionamento no campo acadêmico. Deste modo, a complexa interação entre dominados e dominantes no espaço acadêmico encontra-se traduzida no subcampo marxistas. Neste, desde o início, sobressai a localização periférica das 
mulheres, as quais enfrentam dificuldades ao acesso do núcleo prestigioso composto pela articulação da disciplina filosófica com o clube dos falantes da língua alemã. Núcleo restrito, masculinizado, ocupado pelos herdeiros dos mestres acadêmicos com suficientes recursos financeiros econômicos e simbólicos para recalcar e no mesmo diapasão fazer prevalecer suas origens de classe atravessadas pelas modulações de gênero, étnico-raciais e familiares. Ao final do computo de quase décadas coberto pelo artigo, dois aspectos são sinalizados para futuros desdobramentos sincronizados. Quer dizer, o retorno à formação do campo das humanidades no Brasil à luz da circulação internacional das ideias, mas segundo o empenho de requalificar o conceito de campo, insistindo menos na prerrogativa da autonomia relativa, isto em favor da percepção da unidade complexa e disposta no caudal de inércias e reorientações históricas, a qual envolve domínios intelectuais, suas clientelas, financiadores, instâncias de visibilização/divulgação do conhecimento e meios de expressão, sem esquecer das bases sociomorfológicas em que os(as) primeiros(as) são recrutados(as).

0 reencontro com o problema em torno da autonomia do espaço social da arte se dá em "Intelectuais, Política e Arte: sobre o jogo de ressignificação da autonomia artística”, de Kadma Marques Rodrigues e Diego Soares Rebouças. Contudo, em lugar do terreno próprio ao ethos escolástico-acadêmico, ganha relevo empírico o entremeado dos, circuitos reunindo as artes plásticas e visuais sob os desígnios dos valores do moderno e do contemporâneo. Neste espaço, de olho nas imbricações tão vastas quanto múltiplas da arte contemporânea, os autores perseguem os sinais da emergência de novas funções intelectuais. A ativida- de curatorial lhes atiça a curiosidade, mas sem descuidar dos(as) intervenções de arquitetos e influenciadores midiáticos, por exemplo. A trajetória da narrativa do texto, no entanto, alarga a bitola temporal com o objetivo de rastrear a intelectualização do artístico que se insinua na passagem do século XVIII para o XIX, com o advento das teorias estéticas - base epistemológica para o ingresso da figura do crítico de arte; este último, o cúmplice respaldado em aportes filosóficos, socioantropológicos, psicanalíticos e psicológicos, além da história da arte, das vanguardas modernistas, cujos passos legam ao século XX a conversão revolucionária da percepção, para empregar a chave conceitual com que Bourdieu interpreta os efeitos da presença de Manet. Se a parceria das vanguardas modernistas com os críticos de arte se deu sobre o pacto utópico em torno da promessa do novo, resistindo à acomodação burguesa e, logo, contrapondo-se à acachapante redução à condição de mercadoria, incitada pela estrutura urbano-industrial capitalista, a certa altura do argumento exposto no artigo é sublinhado o deslocamento da tônica. Agora, a profissionalização e inserção nos meandros mercantis não são inimigos a serem combatidos; impõe-se, sim, como dueto alvo de estratégias postas em execução no contexto de uma sociedade na qual estão amalgamados consumo e comércio do conhecimento como informação. Na contramão do profetismo fundado na bandeira da novidade, que alinhou românticos e modernistas, artes e artistas contemporâneos deslocam-se para o plano ordinário, no andamento mesmo em que a estética penetra o cotidiano. Descompromissados com os primados universalistas, porque inteirados a temas pontuais da vida diária num dado momento (identidade se- 
xual e étnico-racial, defesa do direito das mulheres, etc.), os (as) artistas são incitados a deixarem os museus e galerias, na mesma medida em que optam por modalidades processuais de apresentação, em detrimento de objetos. Nessas atmosferas, nas quais a interação e as dialogias se impõem como critérios morais sobre as diretrizes estéticas, um fôlego extraordinário é dado à atividade sistematizante do curador, à intervenção de instaurar ambiências de arquitetos e à competência comutativa de influenciadores midiáticos.

Assinado por Lucas Trindade da Silva, "Gênese e Desenvolvimento da Intelectualidade Neoliberal" segundo Michel Foucault reúne elementos que ajudam a elucidar a rotação artística analisada no artigo anterior. 0 argumento do texto de Silva tem por lastro o compasso das últimas décadas do século, o qual trouxe à cena pública mundial, paulatinamente, os efeitos da reorientação neoliberal de conduta por parte de governantes e mediante eles, mas fazendo dueto com as instâncias parlamentares e jurídicas à redefinição de funções estatais. Com o rigor e a paciência de filatelista, na obra foucaultiana, o autor rastreia propriedades que lhe permite talhar a silhueta da posição do intelectual orgânico neoliberalista. Assim, o artigo acompanha a genealogia construída a partir dos cursos de Foucault (2008a; 2009) sobre biopolítica no College de France. Se o exame pontua as rupturas que leva do advento da economia política no século XVIII aos reposicionamentos liberais em face do Estado previdenciário, a ênfase recai na versão de economia política peculiar ao neoliberalismo estadunidense. A prioridade se justifica pelo deslocamento promovido, afinal, move-se o foco do Estado para o conjunto da sociedade. No translado, de acordo com Foucault, as relações sociais, as interações intersubjetivas e os comportamentos dos indivíduos estão atravessados pelo mesmo desígnio, a saber, o mercado constitui a chave de inteligibilidade, tanto ontológica, quanto formal (epistêmico-cognitiva) da vida coletiva e pessoal. Para Silva, as coordenadas doutrinário-normativas liberais intrínsecas à utopia do mercado absoluto, com impactos já notáveis nas linhas de comando mundo afora, deixando entre seus sinais o incremento da concentração socioeconômica manifestam uma postura intelectual legislativa fundada sobre a legitimidade de uma moralidade com pretensões universalistas, a qual se respalda no apelo à objetividade de uma ciência isenta de valores.

\section{Referências}

ALTAMIRANO, C. Intelectuales. Notas de Investigación. Bogotá: Grupo Editorial Norma, 2006.

ALTAMIRANO, C.; MYERS, J. (Eds.). Historia de los intelectuales en América Latina. Buenos Aires: Katz editores, 2008.

ARON, R. Paz e Guerra entre as Nações. Brasília (DF): UNB/IPRI, 2002.

BADINTER, E. As Paixões e Intelectuais: desejo de glória (1735-1751). Rio de Janeiro: Civilização Brasileira, 2007.

Bajtín, M. Problemas de la Poética de Dostoievski. México (DF): Fondo de cultura económica, 1986.

BAYER, R. História de la Estética. México (DF): Fundo de Cultura Econômica,

2008.

BAUMAN, Z. Legisladores e Intérpretes: sobre modernidade, pós-modernidade e intelectuais. RJ: Jorge Zahar Editor, 2010.

BAUMAN, Z. Mal-Estar na Pós-modernidade. Rio de Janeiro: Jorge Zahar Editor, 1998.

BAUMAN, Z. Modernidade e Holocausto. Rio de Ja- 
neiro: Jorge Zahar Editor, 1998a.

BAUMAN, Z. Modernidade e Ambivalência. Rio de Janeiro: Jorge Zahar, 1999.

BAUMAN, Z. Ética Pós-Moderna. SP: Paulus, 1997. BELL, D. The Cultural Contradictions of Capitalism. Basic Books, 1980.

BELL, D. 0 Advento da Sociedade Pós-industrial: uma tentativa de previsão social. São Paulo: Cultrix, 1977.

BÉNICHOU, P. La Coronación del Escritor (1751830). Ensayo sobre el Advenimiento de un Poder Espiritual Laico en la Francia moderna. Cidade do México: FCE, 1981.

BHABHA, H. K. O Local da Cultura. Belo Horizonte: UFMG, 2001.

BIANCHETTI, L; VALLE, I. R.; PEREIRA, G. M. 0 Fim dos Intelectuais Acadêmicos. Induções da CAPES e Desafios às Associações Científicas. Campinas: Autores Associados, 2015.

BOBBIO, N. Os Intelectuais e o Poder. São Paulo: Unesp, 1997.

BOSCO, F. A Vítima tem Sempre Razão? Lutas identitárias e novo espaço público brasileiro. São Paulo: Todavia, 2017.

BOURDIEU, P. A Distinção: crítica social do julgamento. São Paulo: Edusp, 2007.

BOURDIEU, P. Meditações Pascalianas. Rio de Janeiro: Bertrand Brasil, 2001.

BOURDIEU, P. A Economia das Trocas Lingüísticas. São Paulo: Edusp, 1996 .

BOURDIEU, P. Campo intelectual e projeto criador. In: POUILLON, J. et al. Problemas do Estruturalismo. Rio de Janeiro: Zahar Editores, 1968.

BRIGGS, A.; BURKE, P. Uma História Social da Mídia: de Gutenberg à Internet. Rio de Janeiro, Zahar, 2016.

BURKE, P. Cultura popular na Idade Moderna: Europa, 1500-1800. São Paulo: Companhia das Letras, 2010.
CANDID0, A. Formação da Literatura Brasileira. Belo Horizonte: 1997, 2 vols.

CASTELLS, M. A Sociedade em Rede (A Era da Informação: economia, sociedade e cultura), Vol.I. Rio de Janeiro: Paz e Terra, 1999.

CHARTIER, R. Cultura popular: revisitando um conceito historiográfico. Revista Estudos Históricos, v. 8, n. 16, p. 179-192, 1995.

Chartier, R; Del Priori, M. A Ordem dos Livros: leitores, autores e bibliotecas na Europa entre os séculos XIV e XVIII. Brasília: UnB, 1994.

CLIFFORD, J. A Experiência Etnográfica: antropologia e literatura no século XX. Rio de Janeiro: UFRJ, 2002.

CHARLE, C. Naissance des "intellectuels" (18801900). Paris : Les Éditions de Minuit, 1990.

COSER, L. A. Men of ideas. A Sociologist's view. Nova York: Free Press, 1970.

DA CUNHA, M. C. Relações e dissensões entre saberes tradicionais e saber científico. Revista USP, $n$. 75, p. 76-84, 2007.

DENIS, B. Literatura e Engajamento: de Pascal a Sartre. Bauru: Edusc, 2002.

DERRIDA, J. Gramatologia. São Paulo: Perspectiva, 2008.

DURKHEIM, E. Formas Elementares da Vida Religiosa. São Paulo: Paulínia, 1989.

ELIAS, N. A Sociedade de Corte. Rio de Janeiro: Jorge Zahar, 2001.

ELIAS, N. A Sociedade dos Indivíduos. Rio de Janeiro: Jorge Zahar, 1994.

FARIAS, E. S. de. Sociologia e a esfera cultural contemporânea. Ciências Sociais Unisinos, v. 53, n. 1, p. 3-14, 2017.

FARIAS, E. S.. 0 que pode a triangulação entre dinheiro, expressões culturais e esfera pública nos dizer sobre diversidade e universalidade? Cultura Contemporânea, Identidades e Sociabilidades: olhares sobre o corpo e as novas tecnologias. São Paulo: Cultura Acadêmica, p. 11-40, 2010. 
FERNANDES, F. A Integração do Negro na Sociedade de Classes: no limiar de uma nova era. São Paulo: Globo livros, 2008.

FEUERBACH, L. A Essência do Cristianismo. Campinas: Papirus, 1997.

FOUCAULT, M. Segurança, Território, População. São Paulo: Martins Fontes, 2009.

FOUCAULT, M. Segurança, Território, População: curso dado no Collège de France (1977-1978). Martins Fontes, 2008.

FOUCAULT, M. Nascimento da Biopolítica. São Paulo: Martins Fontes, 2008a.

FOUCAULT, M. 0 que e um autor? In: FOUCAULT, M. Ditos e Escritos: Estética - literatura e pintura, música e cinema (vol. III). Rio de Janeiro: Forense Universitária, 2001. p. 264-298

FOUCAULT, M. ; DELEUZE, G. "Os intelectuais e o poder”. In: Microfísica do Poder, v. 17, p. 69-78, 1979.

FRANCO JÚNIOR, H. A Idade Média: nascimento do ocidente. São Paulo: Brasiliense, 2001.

GAGNEBIN, J. M. 0 rastro e a cicatriz: metáforas da memória. Pro-posições, v. 13, n. 3, p. 125-133, 2002.

GEERTZ, C. Obras e Vidas: o antropólogo como autor. Rio de Janeiro: UFRJ, 2002.

GIDDENS, A. A Constituição da Sociedade. São Paulo: Martins Fontes, 1989.

GLEICK, J. La Información. Barcelona: Crítica, 2011.

GRAMSCI, A. Os Intelectuais e a Organização da Cultura. Rio de Janeiro: Civilização Brasileira, 1968.

GINZBURG, C. 0 Queijo e os Vermes: o cotidiano e as ideias de um moleiro perseguido pela Inquisição. São Paulo: Companhia das Letras, 2017.

GUINSBURG, J. \& BARBOSA, A. M (Edits.). 0 PósModernismo. São Paulo: Perspectiva, 2008.

HABERMAS, J. O Discurso Filosófico da Modernidade: doze lições. São Paulo: Martins Fontes, 2000.
HABERMAS, J. Arquitetura moderna e pós-moderna; Modernidade: um projeto inacabado. In: ARANTES, O. B. F. et al. (Orgs.): Um Ponto Cego no Projeto Estético de Jürgen Habermas: arquitetura e dimensão estética depois das vanguardas. São Paulo, Brasiliense: 1992.

IANNI, 0. Enigmas do pensamento latino-americano. Revista de Ciências Sociais. São Paulo: Instituto de Pesquisa da USP, 2012.

JAMESON, F. A Virada Cultural: Reflexões sobre o Pós-Modernismo. Rio de Janeiro: Record, 2006.

LEÃO, A. B. Fazer do velho uma novidade: as reinvenções dos best-sellers juvenis. Caderno CRH, 29(78), 2017, pp.463-476.

LECLERC, G. Sociologia dos intelectuais. São Leopoldo, RS: Ed. Unisinos, 2004.

LE GOFF, J. Os Intelectuais na Idade Média. São Paulo: Brasiliense, 1989.

LÉVINAS, E. Entre nós. Petrópolis: Vozes, 2005.

LÉVY, P. As Tecnologias da Inteligência. SP: Editora 34, 1993.

LIPOVETSKY, G. ; SERROY, J. A Cultura-Mundo: resposta a uma sociedade desorientada. São Paulo: Companhia das Letras, 2011.

LYOTARD, J.-F. A Condição Pós-Moderna. Rio de Janeiro: José Olympio, 1985.

KUPER, A. The Invention of Primitive Society: transformations of an illusion. Psychology Press, 1988.

MANNHEIM, K. Sociologia da Cultura. São Paulo: Perspectiva, 1974.

MARGATO, I. ; GOMES, R. C. (Eds.). O Papel do Intelectual Hoje. Belo Horizonte: UFMG, 2004.

MARX, K. Manuscritos Econômico-Filosóficos. São Paulo: Boitempo, 2004.

MARX, K. e ENGELS, F. A Ideologia Alemã, Vol. I. Lisboa: Presença. São Paulo: Martins Fontes, s.d, 2 vols.

MAUSS, M. Uma categoria do espírito humano: a noção de pessoa, a de "eu” In: Sociologia e Antropologia. São Paulo: Casac \& Naif, 2003, p. 369- 
397.

MATO, D. Para além da academia. Práticas intelectuais latino-americanas em cultura e poder. In: MARGATO, I.; GOMES, R. C. (Orgs.). O Papel do Intelectual Hoje. Belo Horizonte: Ed. UFMG, 2004.

MICELI, S. Intelectuais à Brasileira. São Paulo: Companhia das Letras, 2001.

MORETTI, F. Atlas do romance europeu: 18001900. São Paulo: Boitempo, 2003.

NETTO, M. N. 0 discurso do marketing de lugar e os grandes eventos. Caderno CRH, v. 29, n. 78, p. 495-511, 2017.

NOVAES, A. O Silêncio dos Intelectuais. São Paulo: Editora Companhia das Letras, 2006.

ORTIZ, R. As celebridades como emblema sociológico. Sociologia \&t Antropologia, v. 6, n. 3, 2016.

ORTIZ, R. Românticos e Folcloristas: cultura popular. Olho d'água, 1992.

ORTIZ, R. Cultura e Identidade Nacional. São Paulo: Brasiliense, 1984.

PASSIANI, Ê. Figuras do intelectual: gênese e devir. Sociologias, Porto Alegre, ano 20, no 47, jan/ abr 2018, p. 16-47.

PÉCAUT, D. Os Intelectuais e a Política no Brasil: entre o povo e a nação. São Paulo: Editora Ática, 1990.

RAMA, A. A Cidade das Letras. São Paulo: Boitempo Editorial, 2015.

RADIN, P. Primitive Man as Philosopher. Courier Corporation, 2002.

ROMANO, E. Sobre o Poder Eclesiástico. Petrópolis: Vozes, 1989.

ROSSI, P. Os Sinais do Tempo. São Paulo: Companhia das Letras, 1992.

ROUANET, S. P. A crise dos universais. In: NOVAES, Adauto (Org.). 0 Silêncio dos Intelectuais. São Paulo: Cia das Letras, 2006.

RUTHERDORD, J. 0 Terceiro Espaço (uma Entrevista com Homi Bhabha). In: Antônio Augusto
Arantes (org.): Revista do Patrimônio Histórico e Artístico Nacional, n. 24, RJ: IPHAN, 1996.

SAID, E. W. Representações do Intelectual: as conferências Reith de 1993. São Paulo: Cia das Letras, 2005.

SARLO, B. A voz universal que toma partido? In: MORAES, D. (Org.). Combates e Utopias. Os Intelectuais num Mundo em Crise. Rio de Janeiro: Record, 2004.

SARLO, B. Cenas da Vida Pós-Moderna: intelectuais, arte e vídeo-cultura na Argentina. Rio de Janeiro: UFRJ, 1997.

SARTRE, J.- P. O Ser e o Nada: ensaio de ontologia fenomenológica. Petrópolis (RJ): Vozes, 1997.

SCHLUCHTER, W. ; ROTH, G. "As origens do racionalismo ocidental”. In: Jessé de Souza (Org.): O Malandro e o Protestante. Brasília: UnB, 1999.

SCHAFF, A. A Sociedade Informática. SP: Brasiliense, 1995.

TAVOLARO, S. "Existe uma modernidade brasileira? Reflexões em torno de um dilema sociológico brasileiro". Revista Brasileira de Ciências Sociais, v. 20, n. 59, p. 5-22, 2005.

THOMPSON, J. B. Mercadores de Cultura. São Paulo: Unesp, 2013.

TOCQUEVILLE, A. de. 0 Antigo Regime e a Revolução. Brasília (DF): UnB,1997.

WINOCK, M. O Século dos Intelectuais. Rio de Janeiro: Bertrand, 1997.

VERGER, J. As Universidades na Idade Média. São Paulo: Unesp, 1990.

TAYLOR, C. Argumentos Filosóficos. São Paulo: Edições Loyola, 2000.

WEBER, M. Sociologia da religião (tipos de relações comunitárias religiosas). In: Economia e Sociedade. Brasília: UnB, 1994.

WOLF, E. R. A Europa e os Povos sem História. São Paulo: Edusp, 2005. 